University of Louisville

ThinkIR: The University of Louisville's Institutional Repository

\title{
Attaining the church universal : imagination, popular theology, and ecumenism in the ministry of S. Parkes Cadman, 1920-1936.
}

James C. Hall 1986-

University of Louisville

Follow this and additional works at: https://ir.library.louisville.edu/etd

\section{Recommended Citation}

Hall, James C. 1986-, "Attaining the church universal : imagination, popular theology, and ecumenism in the ministry of S. Parkes Cadman, 1920-1936." (2011). Electronic Theses and Dissertations. Paper 560. https://doi.org/10.18297/etd/560

This Master's Thesis is brought to you for free and open access by ThinkIR: The University of Louisville's Institutional Repository. It has been accepted for inclusion in Electronic Theses and Dissertations by an authorized administrator of ThinkIR: The University of Louisville's Institutional Repository. This title appears here courtesy of the author, who has retained all other copyrights. For more information, please contact thinkir@louisville.edu. 


\title{
ATTAINING THE CHURCH UNIVERSAL:
}

IMAGINATION, POPULAR THEOLOGY, AND ECUMENISM IN THE MINISTRY

OF S. PARKES CADMAN, 1920-1936

\author{
By \\ James C. Hall \\ B.A., Shawnee State University, 2008
}

\begin{abstract}
A Thesis
Submitted to the Faculty of the

College of Arts and Sciences of the University of Louisville in Partial Fulfillment of the Requirements

for the Degree of
\end{abstract}

Master of Arts

Department of History University of Louisville Louisville, Kentucky

May 2011 

ATTAINING THE CHURCH UNIVERSAL:

IMAGINATION, POPULAR THEOLOGY, AND ECUMENISM IN THE MINISTRY

OF S. SPARKES CADMAN, 1920-1936

By

James C. Hall

B.A., Shawnee State University, 2008

A Thesis Approved on

April 7, 2011

by the following Thesis Committee:

Tracy E. K’Meyer

Dr. Tracy E. K’Meyer, Thesis Director and Professor of History

Christine Ehrick

Dr. Christine Ehrick, Associate Professor of History

John P. Ferré

Dr. John P. Ferré, Associate Dean of Arts \& Sciences and Professor of Communication 


\begin{abstract}
ATTAINING THE CHURCH UNIVERSAL:

IMAGINATION, POPULAR THEOLOGY, AND ECUMENISM IN THE MINISTRY

OF S. PARKES CADMAN, 1920-1936

James C. Hall
\end{abstract}

April 7, 2011

S. Parkes Cadman (1864-1936), a Christian minister at Central Congregational Church in Brooklyn, New York from 1901 to 1936 , was a popular religious figure in interwar America. From 1924 to 1928 , Cadman served as president of the Federal Council of the Churches of Christ in America. Through his utilization of mass media, Cadman became a religious celebrity in the 1920 s. This study analyzes the oratory and written work Cadman produced between 1920 and 1936 and argues that Cadman believed that religious imagination, if properly reached and guided by a Christian minister, would enable the progression of Christian ecumenism. In a time of Protestant division, Cadman expressed his views on imagination and ecumenism over radio station WEAF, New York from 1923 to 1936 and in several seminal books, including Ambassadors of God (1920), Imagination and Religion (1926), Answers to Everyday Questions (1930), and Imagination (1930). 


\section{TABLE OF CONTENTS}

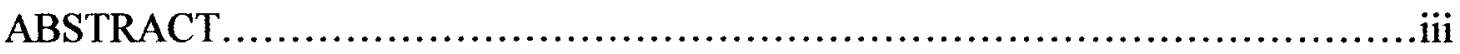

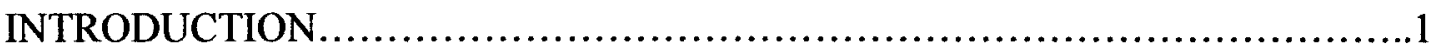

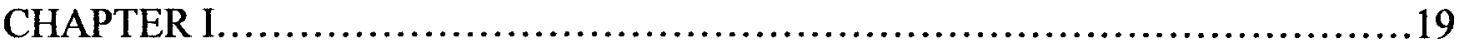

The Life and Work of S. Parkes Cadman

CHAPTER II.....................................................................

S. Parkes Cadman's Theory of Imagination

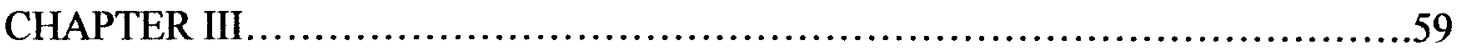

S. Parkes Cadman and Popular Theology

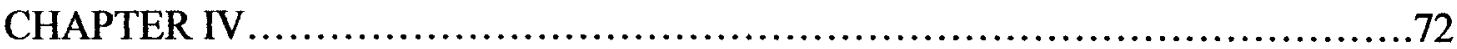

Ecumenism in the Ministry of S. Parkes Cadman

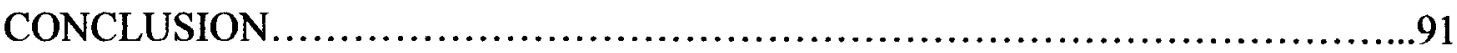

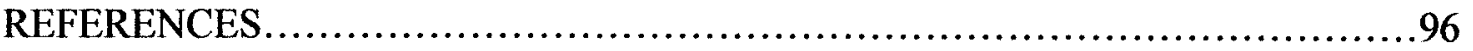

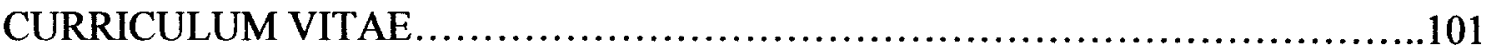




\section{INTRODUCTION}

On a Sunday afternoon in March, 1923, churchgoers from a number of denominations in the small town of Cornwall-on-Hudson, New York gathered at the local Episcopal church in order to listen to a radio broadcast from Bedford, New York. The men and women present had collectively written a letter to a popular minister who, for three months prior, had preached over station WEAF. Still in its infancy, interactive radio preaching carried a level of excitement. The letter asked a question that, like the communal act of listening to the broadcast, was ecumenical in nature: "Do you think that all churches should get together?" As the radio crackled to life and the Bedford announcer introduced the week's sermon, the men and women listening in the Cornwallon-Hudson church had no way of knowing for certain that their question would be addressed over the airwaves. They waited as the minister delivered a thirty-minute sermon. They waited as the Gloria Trumpeters performed several hymns. ${ }^{1}$ Finally, the minister began his popular question-and-answer session. Near the end of the program, the minister read from the Cornwall-on-Hudson letter: "Do you think that all churches should get together?" Without hesitation, the minister answered, "I do. I would like to see all the churches in New York get together tonight." The minister, a man who left a legacy of

\footnotetext{
${ }^{1}$ Formed in 1914, the Gloria Trumpeters consisted of Katherine Williams, Louise Gura, Cora Roberts, and Mabel Coapman. See S.W.S, "'Give Truth the Open Field---," The Wireless Age, April, 1923, 29.
} 
both radio preaching and ecumenical discourse, was S. Parkes Cadman. ${ }^{2}$ In this instance, the message he delivered and the manner in which he delivered it go a long way in summing up his influential ministry.

Although marginalized in historical scholarship and largely forgotten today, S. Parkes Cadman, who made a career in America from 1890 to 1936, was a popular figure in his time. Cadman's most fruitful work came in the years following World War I when, as a radio preacher in New York, he reached a wide and diverse audience. Cadman's listenership grew throughout the 1920 s and expanded during the Depression years. A liberal Protestant (first Methodist and then Congregationalist), Cadman favored the marriage of religion and science in a time when those ways of thinking seemed to be at war with each other. He believed in the unity of knowledge, but Cadman's most important work lay in another type of unity: Christian ecumenism.

Throughout his long and successful career, Cadman sought avenues with the most potential for bringing the Church Universal (a unified Christianity without denominations) into existence. Cadman saw Christianity as encompassing all individuals, regardless of race, nationality, or sex, who accepted Jesus Christ as the son of God and as the savior of mankind. Beyond the complication of doctrine, Cadman maintained, all Christian denominations believed in the same things. Ecumenism, in the context of this study, is defined as the method by which doctrinal differences between adherents of denominational Christianity are reduced or eliminated in favor of recognizing the similarity of beliefs. Ecumenism, in other words, seeks to erase denominational lines within Christianity and to assuage misunderstandings in order to establish a single

\footnotetext{
${ }^{2}$ S.W.S, "'Give Truth the Open Field---," The Wireless Age, April, 1923, 29. Halsey Hammond, secretary of the Bedford, NY Y.M.C.A., related this story to the article's author. The Wireless Age, a periodical devoted to everything radio, billed itself as "America's Foremost Radiophone Review."
} 
Church Universal. Cadman was not one-dimensional in his endeavors; many causes demanded his attention. The writings he left behind reveal a mind that found many facets of life and religion worth his time and effort. At different times, Cadman focused on such diverse topics as evolution, prohibition, racism, the social gospel, modernity, academia, technology, theology in its many manifestations, literature, and film. Regardless, Cadman returned time and again to the topic of Christian ecumenism. Cadman dealt with the topic in a light manner and in a scholarly manner; he preached ecumenism to his fellow ministers and to everyday people across the country. Ecumenism was the matter that, he believed, most deserved his directed effort, energy, and attention. The manner by which Cadman believed ecumenical activity could work is the focus of this study.

Imagination was central to Cadman's approach to ecumenism. Cadman defined imagination as the uniquely human faculty that allows an individual to transform exterior phenomena into accessible images in the mind. Memory is an extension of imagination, Cadman argued, constituting the body of mental images associated with the past experience of an individual person and the history of their culture. Imagination becomes religious imagination when the faculty is employed in connection with matters of religion (from reading a biblical passage to praying to writing a sermon). Cadman believed ecumenism required the cooperation of individuals with a properly guided religious imagination. The imagination constituted a world of both peril and promise; it could soar, but it could also go sour. It could heal religious schisms, or it could exacerbate them. Therefore, Cadman developed ideas about how he could best reach and guide the imagination of his listeners and readers. 
Over the course of his ministry, Cadman came to believe in the power and utility of popular theology. Although not a term used in the American interwar years, "popular theology" is helpful for categorizing Christian thought that is crafted to suit the understanding of average men and women. Cadman's popular theology is defined as the system of inquiry and the method of discourse he applied to questions concerning Christianity. Popular theology is "popular" in the sense that Cadman answered these questions in a manner suited to the understanding of the average person. Cadman's popular theology also dealt with the language and method of effective communication. Central to this system of inquiry was the question: how does a minister most effectively communicate to a mass audience? In this sense, popular theology is conceptually similar to missiology, the study of missionary activity within Christian theology. ${ }^{3}$ Both missiology and popular theology are instances of practical theology, which is theology applied to everyday living. Cadman believed that an accessible Christian message disseminated through mass media was the best method for reaching the imagination of the greatest number of individuals. Inclusive rather than exclusive, popular theology directly contrasts with the method and language of academic theology as practiced in seminaries and aimed at learned, informed individuals.

Considering the span of Cadman's career, why do the years 1920 to 1936 stand out? During the last sixteen years of his life, Cadman pursued, with his greatest effort, Christian ecumenism. Cadman published Ambassadors of God, his collection of lectures dealing with the ideal Christian minister, in 1920. In these lectures, Cadman laid out, for the first time, his ideas about Christian ecumenism. In addition, he discussed the importance of the Christian minister in reaching the common person. From 1920 to 1936,

\footnotetext{
${ }^{3}$ Missiology, too, deals with methods of effective communication.
} 
Cadman fine-tuned his thoughts on imagination, accessible and inclusive Christianity (popular theology), and ecumenism. He produced the most important books of his career during this fertile period, including Imagination and Religion (1926), The Christ of God (1929), Answers to Everyday Questions (1930), and Imagination (1930). Between 1920 and 1936, Cadman argued that Christian ecumenism depended on the religious imagination of individual Christian adherents. Simple and accessible religious messages delivered through mass media, he maintained, allowed the minister to best reach and guide the imagination of individual Christian adherents.

This study relies on scholarship from two distinct fields of American history: the history of modern Christianity and the history of mass media. The historical scholarship on Christianity in interwar America is vast and detailed. With a few important exceptions, most avenues open to historians have been investigated, albeit, with varying degrees of depth and success. Although the historical scholarship on American media (especially radio) is less comprehensive than that on Christianity, in recent decades the field of media studies has enjoyed a surge of historical scholarship. The historical record continues to become clearer, although it is still littered with gaps.

Cadman's writings and oratory concerning imagination, popular theology, and ecumenism are embedded in the broad context of interwar Christianity and popular culture. Two books in particular are foundational in understanding the culture and thought of interwar America: Richard H. Pells' Radical Visions and American Dreams: Culture and Social Thought in the Depression Years $(1973,1998)$ and Terry A. Cooney's Balancing Acts: American Thought and Culture in the 1930s (1995). 
Pells' text features his influential argument that American intellectual culture underwent two changes, and issued in two distinct phases over the interwar years. The first change, from the latter years of the 1920s to the early stages of the Depression, was a transition from "detached individualism" to collectivism. The shift involved writers and academics who held socialist tendencies and generally leaned to the left of the political spectrum. However, the urge to collective living and thinking did not persist. Pells demonstrates that radical philosophies, by the end of the decade, turned to conservativeminded reaffirmations of the American myth. Pells explains,

The intellectual's century-long missionary zeal to serve society and shape the course of history led him gradually to suspend his critical faculties. Inexorably, he moved from rebellion to 'responsibility,' from dissent to affirmation, from an interest in the avant-garde to a fascination with the mass media, from a concern for ideology to an obsession with symbols and myths, from an unlimited investigation of social issues to a ritual glorification of America. ${ }^{4}$

In Balancing Acts (1995), Terry A. Cooney discusses the intellectual side of 1930s culture. Cooney generally investigates intellectual activity at the expense of common individuals. Regardless, the author, who owes a great deal to the work of Pells, puts forth a solid argument about the often contradictory views that prevailed during the 1930s. Cooney's most insightful discussions concern 1930s popular culture. Radio, print media, and cinema are equally discussed in his text, with the overall conclusion that popular culture for audiences in the 1930s reflected an environment alien to their reality but familiar to their imagination - a world removed from the reality of economic depression and based in myths prevalent in 1920s culture. Mass entertainment was escapist. Although Cooney focuses on 1930s thought and culture, he does not cover the matter of religion in great detail. A study of Cadman's life connects both popular culture

\footnotetext{
${ }^{4}$ Richard H. Pells, Radical Visions and American Dreams (Chicago: University of Illinois Press, 1998), 367.
} 
and religion in the period studied by Pells and Cooney. Cadman used radio and print media to spread ideas prevalent in religious and secular culture. He also dealt directly with the intellectual trends discussed by Pells that prevailed before and during the Great Depression. Several questions featured in Cadman's text Answers to Everyday Questions (1930), for example, deal with the intellectual attraction of socialism. ${ }^{5}$

S. Parkes Cadman operated within a larger system. Like popular culture, broad currents in Christian thought and method influenced Cadman's strategies for pursuing Christian ecumenism. In the field of interwar Christianity, four works stand out: Modern American Religion Volume 2: The Noise of Conflict, 1919-1941 (1991) by Martin E. Marty; Douglas Horton and the Ecumenical Impulse in American Religion (2002) by Theodore Louis Trost; Stephen Charles Neill's essay "Plans of Union and Reunion, 1910-1948" (1953); and The Making of American Liberal Theology: Idealism, Realism, and Modernity, 1900-1950 (2003) by Gary Dorrien. All four works are important tools for developing a full understanding of Christianity (especially liberal Protestantism) during the American interwar years.

Martin E. Marty's monumental three-volume history of "Modern American Religion" spans sixty-seven formative years, 1893 to $1960 .^{6}$ The second volume, The Noise of Conflict, is most relevant to this study. Because Marty, a distinguished scholar in the field, allows his roots and biases to show in the material he chooses to present, the history is not as comprehensive as the title suggests. Rather, it is a history that focuses on Christianity, particularly the upper-echelon of Christianity - the type found in seminaries

\footnotetext{
${ }^{5}$ See S. Parkes Cadman, Answers to Everyday Questions (New York: The Abingdon Press, 1930), 73-74. The question on pages 73 and 74 features a mother asking Cadman's advice about dealing with her daughter, in college, who had recently become intensely interested in socialist ideas. After a discussion of socialism, Cadman attributed the daughter's interest to "growing pains."

${ }^{6}$ The Irony of It All, 1893-1919; The Noise of Conflict, 1919-1941; and Under God, Indivisible, 1941-1960.
} 
and universities. Within that framework, Marty demonstrates that erupting fissures defined American religion (specifically Protestantism) and that "conflict between peoples and among peoples was the most important public religious theme in the period between the two world wars." Furthermore, he adds that "in matters specifically religious the nation had never seemed more divided." ${ }^{.8}$ After World War I, the fissure between fundamentalist and liberal Protestants grew to new proportions. The conflict, especially after the publicity of the Scopes Trial (1925), dominated the nation's headlines concerning religious matters. Marty concentrates on conflict, but he also acknowledges that ecumenical currents existed and gained momentum in the face of Protestant division. For Cadman and others like him, the modernism debate was not only about keeping Christianity current by incorporating newfound knowledge; it was also about keeping Christianity modern by keeping it strong, by expanding its size through unification. Although ecumenical philosophy did not dominate the religious landscape of $1920 \mathrm{~s}$ America, it was an important theme for many Christian leaders.

Theodore Louis Trost expanded upon Marty's work in Douglas Horton and the Ecumenical Impulse in American Religion (2002). Cadman figures prominently in Trost's insightful book. Trost maintains that Cadman influenced the ecumenical concepts developed by Douglas Horton in such works as The Basic Formula for Church Union (1933). ${ }^{9}$ Trost writes that, "Before the word 'ecumenical' was in common use, Cadman

\footnotetext{
${ }^{7}$ Martin E. Marty, Modern American Religion Volume 2: The Noise of Conflict, 1919-1941 (Chicago: The University of Chicago Press, 1991), 2.

${ }^{8}$ Ibid., 3.

${ }^{9}$ Douglas Horton (1891-1968) first listened to Cadman preach in 1905 when he was fourteen years old. Horton would go on to become an ecumenical leader in twentieth-century Christianity. In addition to the many influential books he published, Horton served as the dean of Harvard Divinity School from 1955 to 1960.
} 
was an ecumenical pioneer. And Douglas Horton was his youthful apprentice."10 Marty's text helps in understanding the religious atmosphere of interwar America and Trost's discussion of Christian ecumenism is a useful supplement.

With few exceptions, Christian ecumenical activity has not been covered by recent historical scholarship. ${ }^{11}$ To date, the most important and most comprehensive work remains the 1954 compendium of essays entitled A History of the Ecumenical Movement, 1517-1948, edited by Stephen Charles Neill and Ruth Rouse. ${ }^{12}$ Reviewing the second edition in 1971, John F. Piper Jr. asserted that the essays "are basic to any study of the ecumenical movement.... Their scope provides... a narrow angle view of developments within this century by ecumenical theologians and statesmen." 13 Stephen Charles Neill's "Plans of Union and Reunion, 1910-1948," a fifty-one page essay with a helpful appendix presenting a list of every Christian denominational union from 1910 to 1948 , is essential for understanding ecumenical activity during the American interwar years. Neill argues that, "The forty years between 1910 and 1950 have achieved more towards the overcoming of differences between Christians, and towards the recovery of the lost unity of the Body of Christ, than any period of equal length in the previous history of the

\footnotetext{
${ }^{10}$ Theodore Louis Trost, Douglas Horton and the Ecumenical Impulse in American Religion (Cambridge, MA: Harvard University Press, 2002), 28.

" Exceptions include the Historical Dictionary of Ecumenical Christianity (1994); Trost (2002); the Dictionary of the Ecumenical Movement (2003); and The Ecumenical Movement: An Introductory History (2004) by Thomas E. Fitzgerald.

${ }^{12}$ The Westminster Press published a second edition of the text, "with revised bibliography," in 1967. A second volume, entitled The Ecumenical Advance: A History of the Ecumenical Movement, 1948-1968 appeared in 1970.

${ }^{13}$ John F. Piper Jr., "Untitled Review," review of $A$ History of the Ecumenical Movement, ed. Routh Rouse et al., Journal for the Scientific Study of Religion, Vol. 10, No. 4 (Winter, 1971): 400-401, http://www.jstor.org/stable/1384790. A respected historian, Piper is the author of Robert E. Speer: Prophet of the American Church (2000). Speer preceded Cadman as president of the Federal Council of the Churches of Christ in America, serving from 1920-1924.
} 
Christian Churches. ${ }^{\prime 14}$ Neill's argument conflicts with Marty's study of interwar religion. Although Marty discusses ecumenism in The Noise of Conflict, he maintains that ecumenism was a subtext during the interwar years. Neill, in contrast, argues that ecumenism was a major facet of interwar Christianity. Neill downplays conflict, whereas Marty elevates conflict. Neill's investigation, along with his comprehensive bibliography, makes for the most authoritative account of Christian ecumenism in the first half of the twentieth century.

The most recent contribution to the field, Thomas E. Fitzgerald's The Ecumenical Movement: An Introductory History (2004) is valuable for understanding the complete history of Christian ecumenism. However, the text covers nearly two-thousand years of history. As an overview of the quest for Christian unity, Fitzgerald's text is indispensable. For specific details on ecumenical activity between 1910 and 1948, Neill's essay remains the standard text.

Gary Dorrien, like Marty, produced a monumental three-volume history of American religion. ${ }^{15}$ Although Dorrien's texts cover a larger span of time (1805-2005), their focus is more specific than Marty's volumes. Dorrien investigates the roots and continuing influence of liberal theology in America. The Making of American Liberal Theology: Idealism, Realism, and Modernity, 1900-1950 is not comprehensive, but does lay out many important themes relevant to this study. Like Marty, Dorrien keeps his argument confined to the upper-echelon of Christian culture, asserting that "The major

\footnotetext{
${ }^{14}$ Stephen Charles Neill, "Plans of Union and Reunion, 1910-1948," in A History of the Ecumenical Movement, 1517-1948, ed. Ruth Rouse et al. (Philadelphia: The Westminster Press, 1967), 445.

${ }^{15}$ Imagining Progressive Religion, 1805-1900; Idealism, Realism, and Modernity, 1900-1950; and Crisis, Irony, and Postmodernity, 1950-2005.
} 
theorists of American liberal theology during its field-dominating phase were academic theologians." 16

Dorrien maintains that conflict between fundamentalists and modernist liberals was the most important theme in Protestant Christianity during the interwar years, agreeing with Marty and conflicting with Neill. He also agrees that liberal Protestants enjoyed a privileged position in the scarred religious landscape following World War I. However, Dorrien better demonstrates the changing focus of liberal Protestants after the onset of the Great Depression than Marty. Modernism, although important to Dorrien's conception, was not the only driving force behind liberal Protestantism in interwar America. The author explains, "Depression-era Americans knew for a certainty that progress had stopped; their world was filled with insecurity and dreadful deprivations, and the mannered ideals of Victorian moralism were alien to them." ${ }^{17}$ Harry Emerson Fosdick, Dorrien maintains, changed his outlook with the times. Fosdick returned to an emphasis on personal sin in the 1930 s, maintaining that the sins of progress, of modern culture, could no longer be ignored.

Although the histories written by Marty and Dorrien are important for understanding the major currents of Christianity in the interwar years, the books are not without problems. By focusing their studies on the intellectual upper-echelon of Christian society, Marty and Dorrien overlook how common people experienced religion. Religion is not relegated to intellectuals. By focusing on the academic side of American religion,

\footnotetext{
${ }^{16}$ Gary Dorrien, The Making of American Liberal Theology: Idealism, Realism, and Modernity, 1900-1950 (Louisville, KY: Westminster John Knox Press, 2003), 356.

${ }^{17}$ Ibid., 389.
} 
Marty and Dorrien downplay the important role of the ecumenical activity in interwar America discussed by Neill, and, therefore, only demonstrate one side of the story. ${ }^{18}$

In addition, Marty and Dorrien omit the role of popular media in the dissemination of Christianity. The intellectual debates between Christians during the interwar years were often spread among non-scholarly laity through mass media. In the 1920s and 1930s, popular media - particularly print and radio - helped bring new and traditional Christian ideas to the American public. Capable scholars have investigated religious radio and religious book publishing at some length. The work in the field, although not comprehensive, continues to grow. Religion and media studies gained momentum in the 1980s, and since that time scholars have completed a good deal of solid scholarship on the subject. Douglas Carl Abrams' book Selling the Old-Time Religion: American Fundamentalists and Mass Culture, 1920-1940 (2001), for example, recently filled the long-standing gap in the study of evangelical radio during the interwar years. Tona Hangen backs up Abrams' study with her important article "Man of the Hour: Walter A. Maier and Religion by Radio on the Lutheran Hour." 19 In the last two decades, several books have investigated liberal Protestant radio. These works include Hal Erickson's Religious Radio and Television in the United States, 1921-1991: The Programs and Personalities (1992); R. Laurence Moore's Selling God: American Religion in the Marketplace of Culture (1994); Tona Hangen's Redeeming the Dial: Radio, Religion, and Popular Culture in America (2002); and Robert S. Fortner's

\footnotetext{
${ }^{18}$ Richard J. Callahan Jr.'s Work and Faith in the Kentucky Coal Fields: Subject to Dust (2009), published by Indiana University Press, is an example of a study that deals with religion from the common man's perspective.

${ }^{19}$ See Tona Hangen, "Man of the Hour: Walter A. Maier and Religion by Radio on the Lutheran Hour," in Radio Reader: Essays in the Cultural History of Radio, ed. Michele Hilmes et al (New York: Routlege, 2002), 113-134.
} 
Radio, Morality, and Culture: Britain, Canada, and the United States, 1919-1945 (2005). All of these books are useful, and each provides a unique perspective on the topic of liberal Protestant radio. Erickson provides an in-depth survey of religious programs featured on radio (with an emphasis on the major networks: NBC, CBS, MBS, and $\mathrm{ABC}$ ); Moore places interwar religious radio in the context of other forms of mass media such as magazines and books; Hangen provides an insightful overview of radio's place in religion and popular culture; and Fortner discusses the thoughts and broadcasting philosophies that dictated what type of religious programs made it on the air during the interwar years. S. Parkes Cadman, for the majority of his radio career, spoke over the NBC radio network. Louise M. Benjamin's The NBC Advisory Council and Radio Programming, 1926-1945 (2009) is the most helpful work to date for untangling the complexities involved with religious broadcasting at NBC. Benjamin's text filled a gap in the historiography of the field, investigating the formation of NBC's advisory council and the effect it had on the programming featured over NBC's stations, especially programming that constituted public service time. Previously, Douglas B. Craig's influential Fireside Politics: Radio and Political Culture in the United States, 1920-1940 (2000) provided the most informative treatment of NBC's advisory council. However, Craig does not focus on the council, so his text lacks the comprehensiveness of Benjamin's monograph.

Benjamin argues that NBC's Advisory Council's "policy pronouncements greatly influenced all broadcasters' carriage of religious programming." ${ }^{20}$ Benjamin is the first to go in-depth about the specifics involved in the formation of NBC's Committee on

\footnotetext{
${ }^{20}$ Louise M Benjamin, The NBC Advisory Council and Radio Programming, 1926-1945 (Carbondale, IL: Southern Illinois University Press, 2009), 10.
} 
Religious Activities, explaining that Owen Young and Merlin Aylesworth (President of NBC) "selected three men to represent what they considered the dominant American religious denominations - Jewish, Catholic, and Protestant."21 The three men chosen for the committee - Julius Rosenwald, Morgan J. O'Brien, and Charles F. MacFarland were business leaders or religious leaders. Interestingly, MacFarland was an example of both. In the late nineteenth century, MacFarland worked as general manager for T.O. Gardener \& Company, Manufacturers, and from 1912 to 1931, he held the position of "social services secretary" for the Federal Council of the Churches of Christ in America (FCCCA). ${ }^{22}$ Benjamin reveals that the Committee on Religious Activities sponsored groups rather than individual speakers. For example, rather than sponsoring S. Parkes Cadman, the committee sponsored the FCCCA, a group for which Cadman served as president from 1924-1928.

The works on religious publishing are not as abundant as the scholarship on religious radio. However, one article helps in understanding the field. Joan Shelley Rubin investigates the topic of religious publishing during the interwar years in her 1999 article "The Boundaries of American Religious Publishing in the Early Twentieth Century." Rubin focuses on the 1920s and 1930s, arguing that religious publishing in the interwar years "may be a more capacious term than scholars have consistently recognized."23 Religious books were not only concerned with theological issues; works that fell under this broad banner used religion in a number of ways for a number of goals. Rubin stresses that both small religious publishing houses and major book publishers of the period,

\footnotetext{
${ }^{21}$ Ibid. 17.

22 Ibid., 18.

${ }^{23}$ Joan Shelley Rubin, "The Boundaries of American Religious Publishing in the Early Twentieth Century," Book History 2 (1999): 207, http://www.jstor.org/stable/30227303.
} 
precisely because of the genre's fluidity, published religious works. For instance, Macmillan and Harper led the field in religious publishing. ${ }^{24}$

S. Parkes Cadman utilized both radio and religious publishing to spread his message. Although Cadman was an important religious figure in his time, historical scholarship has not treated him fairly. He has been overshadowed by the more colorful figures of his age. In the last two decades, for example, scholars have published biographies of Aimee Semple McPherson and Charles E. Coughlin, but the last published work on Cadman appeared in $1967 .{ }^{25}$ Unfortunately, it is not a great labor to compile an exhaustive list of works that deal directly with Cadman. The texts include a chapter by Joseph Fort Newton in Some Living Masters of the Pulpit: Studies in Religious Personality (1923); Henry F. Pringle's 1928 compilation of biographical sketches, unhelpfully titled Big Frogs; Fred Hamlin's "authorized" biography, S. Parkes Cadman: Pioneer Radio Minister (1930); American Preachers of To-day: Intimate Appraisals of Thirty-Two Leaders (1933) by Edgar DeWitt Jones; ${ }^{26}$ a 1937 Bachelor of Divinity thesis, "S. Parkes Cadman as a Preacher," written by J. Bruce Vardam at Emory University; Dr. S. Parkes Cadman: Preacher, Pastor, and Ecumenical Prophet (1967), a sixty-five page pamphlet by Henry Smith Leiper and Edward Daniel Staples; ${ }^{27}$ and, most recently, an unpublished 1986 Doctor of Theology dissertation entitled "Religious Imagination in Twentieth Century American Theology: A Study of Four Selected Figures," written by Don M. Aycock for New Orleans Baptist Seminary. Four of these writings were

\footnotetext{
${ }^{24}$ Ibid., 209.

${ }^{25}$ Aimee Semple McPherson and the Resurrection of Christian America (2007) by Matthew Avery Sutton and Radio Priest: Charles Coughlin, The Father of Hate Radio (1996) by Donald I. Warren.

${ }^{26}$ Edgar DeWitt Jones served as President of the Federal Council of the Churches of Christ in America from 1936-1940.

${ }^{27}$ Leiper compiled the pamphlet for The Congregational Christian Historical Society. Leiper utilized an unpublished manuscript written by Staples in 1932. He expanded and updated Staples' original text and published the pamphlet as a whole in 1967.
} 
produced during the height of Cadman's popularity; one was produced the year after Cadman's death; and of the remaining two, one is a pamphlet and the other is a dissertation that features a forty-page chapter on Cadman.

Scholarship on Cadman is largely relegated to the biographical. The method and thought of his ministry have yet to be investigated adequately. Cadman's numerous books have not been analyzed in any detail. His radio work, too, has been ignored by scholars investigating religion and media. Even writings that focus on Cadman's radio career, such as Fred Hamlin's 1930 biography, provide only historical accounts of Cadman's rise to prominence rather than dealing with the material in an analytical way. Regardless of their deficiencies, the available texts are important in regard to the historical record. S. Parkes Cadman: Pioneer Radio Minister (1930) and Dr. S. Parkes Cadman: Preacher, Pastor, and Ecumenical Prophet (1967) are the most informative and insightful. The former is valuable because it focuses on the history of Cadman's radio work and the latter is significant because it ponders the extent of the minister's ecumenical activities.

Cadman is mostly absent from the broader works on interwar religion and popular culture. Martin E. Marty mentions the minister once, without any detail, in connection to his ecumenical zeal. ${ }^{28}$ Gary Dorrien and Stephen Charles Neill do not discuss Cadman. Theodore Louis Trost gives a brief overview of Cadman's career and discusses how Cadman influenced Douglas Horton. ${ }^{29}$ Tona Hangen, in Redeeming the Dial: Radio, Religion, and Popular Culture in America (2002), briefly mentions Cadman in connection to his service on NBC's National Radio Pulpit without investigating his

\footnotetext{
${ }^{28}$ Marty, The Noise of Conflict, 36.

${ }^{29}$ Trost, Douglas Horton, 23-28, 41, 49.
} 
career or the importance of his radio work. ${ }^{30}$ Hal Erickson's compendium, Religious Radio and Television in the United States, 1921-1991: The Programs and Personalities (1992), mentions Cadman one time, but only in relation to National Radio Pulpit. ${ }^{31}$ Robert S. Fortner briefly describes Cadman's influence on the liberal Protestant approach to radio broadcasting in his volume, Radio, Morality, and Culture: Britain, Canada, and the United States, $1919-1945$ (2005).${ }^{32}$ Otherwise, Cadman is absent from the historical record. This study seeks to remedy the glaring gap concerning Cadman's life and work.

Although unrecognized today, Cadman was so popular in his time that contemporaries considered him an "institution." ${ }^{" 33}$ It is difficult to describe the popular status once held by a forgotten man. A quotation from Cadman's time sums up his popularity best. Edgar DeWitt Jones, in 1933, wrote, "He is the best known clergyman in America, not excepting Dr. Fosdick. One thinks of him along with Will Rogers, Henry Ford, Amos ' $n$ ' Andy. ${ }^{34}$ Jones listed Cadman's name among figures that, for better or worse, are forever tied to American popular culture. Why, then, has Cadman been neglected in historical scholarship? Judging by trends in recent historical literature, two facets of Cadman's career have aided in his exclusion from the record: first, Cadman was mainly recognized as a radio figure during his time; and second, as a religious figure, Cadman preached and wrote in a popular rather than academic vein. The history of radio is incomplete and, as such, many important radio personalities have yet to be analyzed

\footnotetext{
${ }^{30}$ Tona Hangen, Redeeming the Dial: Radio, Religion, and Popular Culture in America (Chapel Hill: University of North Carolina Press, 2002), 24.

${ }^{31}$ Hal Erickson, Religious Radio and Television in the United States, 1921-1991: The Programs and Personalities (Jefferson, NC: McFarland \& Company, Inc., 1992), 43.

${ }^{32}$ Robert S. Fortner, Radio, Morality, and Culture: Britain, Canada, and the United States, 1919-1945 (Carbondale, IL: Southern Illinois University Press, 2005), 111, 115, 119.

${ }^{33}$ Edgar DeWitt Jones, American Preachers of To-day (Freeport, NY: Books for Libraries Press, 1971), 303.

${ }^{34}$ Ibid.
} 
and written about. And in recent scholarship on interwar Christianity, academic figures have been analyzed in favor of popular religious figures.

Despite his near absence from the historical record, S. Parkes Cadman contributed a great deal to the marriage of religion and mass media, to conceptions of religious imagination, and to ecumenical philosophy in twentieth-century Christianity. Cadman believed that ecumenical activity was more than an elite pursuit. For Christian ecumenism to be successful it had to come from the bottom up. The story of Cadman's life and work helps to fill a gap in the historiography of the field by addressing several questions concerning liberal Protestantism during the interwar years. For instance, what tools did the radio offer a minister seeking Christian ecumenism? How did Cadman approach radio preaching? What did the minister seek to instill in his audience? In a time of Protestant division, what did an "ecumenical prophet" of the interwar years have to say about the future of Christianity? In what manner did Cadman believe ecumenical progress could be accomplished? Cadman's story and the work he produced help in answering these important questions. 


\section{CHAPTER I:}

\section{THE LIFE AND WORK OF S. PARKES CADMAN}

To understand the work of S. Parkes Cadman, it is necessary to understand his life and times. Cadman's personal experiences and the intellectual trends of his day shaped his contributions to religious imagination, popular theology, and ecumenism. For instance, the tenets of Romanticism influenced Cadman's liberal theology, especially his theory of imagination; the development of radio gave direction to his use of mass media; and the fundamentalist/modernist schism made Christian unity an urgent priority. Cadman preached in America from 1890 until his death in 1936. In a ministry that spanned five decades and two Protestant denominations, Cadman shaped the ideas that are central to this study.

The man who would one day be known as the "Dean of Religious Radio" began his life in a humble setting. ' Samuel Parkes Cadman was born on December 18, 1864 in Shropshire, England to Samuel Cadman and Betsy Cadman (née Parkes). His father, Samuel Cadman, worked in a mine that he owned and as a lay preacher for the Methodist church on the side. Cadman's grandfather, Robert, and his uncle, Henry, also practiced as lay preachers in the Methodist tradition. The Cadmans had owned coal mines for more than one-hundred and fifty years and at the time of Cadman's 1864 birth, Henry

\footnotetext{
${ }^{1}$ Robert S. Fortner, Radio, Morality, and Culture: Britain, Canada, and the United States, 1919-1945 (Carbondale, IL: Southern Illinois University Press, 2005), 111.
} 
and Samuel Cadman co-owned the Little Hays Pit. ${ }^{2}$ It was a business of subsistence rather than wealth, however.

Following the family business, S. Parkes Cadman went to work in the mines at the age of twelve. ${ }^{3}$ At that time, he worked as a "pony boy," loading coal into pony cars and hauling it to the entrance of a shaft to be lifted out. He worked five days a week, from six in the morning until three in the afternoon. According to Cadman's biographer Fred Hamlin, it was at this point in his life that he developed the habit of voracious reading. ${ }^{4}$ Hamlin writes that, "Up at four o'clock in the morning, the mines occupied him until three in the afternoon. He got home at four, slept until six or seven, ate supper, and then read until all hours of the night .... Anything in print was grist for his mill."5 Although Cadman followed in his father's footsteps as far as coal mining was concerned, the future preacher was not quick to follow his father into church service. In fact, Cadman was slow to pronounce his faith in Christianity. Leiper and Staples explain, "Dr. Cadman did not publicly commit himself to Christ until about sixteen years of age, when the Reverend J. Montgomery Pascoe, an evangelist of the Wesleyan Methodist Church, came to the nearby town of Dawley." Once Cadman had publicly accepted the Christian faith, his movement into the service of the Church evolved quickly. By seventeen, he had preached his first sermon. At twenty, he received licensure to practice as a lay preacher. But Cadman's ambition was not to be relegated to small country

\footnotetext{
${ }^{2}$ Fred Hamlin, S. Parkes Cadman: Pioneer Radio Minister (New York: Harper \& Brothers Publishers, 1930), 20.

${ }^{3}$ Hamlin writes that Cadman was twelve years old at the time. Leiper and Staples (1967), however, contend that Cadman was eleven when he went to work in the Little Hays Pit.

${ }^{4}$ Hamlin's text reads like modern hagiography at times. However, what may be hyperbole, in this case, serves to illustrate something of Cadman's studious habits.

${ }^{5}$ Hamlin, S. Parkes Cadman, 24.

${ }^{6}$ Henry Smith Leiper and Edward Daniel Staples, Dr. S. Parkes Cadman: Preacher, Pastor, and Ecumenical Prophet (Boston: The Congregational Christian Historical Society, 1967), 2-3.
} 
churches and preaching sermons between shifts in a coal mine. At age twenty-one, Reverend W.S. Bestall sponsored Cadman as a candidate for the Methodist ministry, enabling the young man to take the entry examination for Richmond College of the University of London - the center for training Methodist ministers in 1880s England. ${ }^{7}$ Upon passing the examination, in 1886, Cadman was admitted to Richmond College with a scholarship.

As a student at Richmond, Cadman encountered both the framework of liberal theology and the influential tenets of Romanticism. A "conservative liberal" by his own definition, Cadman emphasized the importance of "feeling" as the basis of religion. Philosophically, the liberal theology of Protestantism developed in a Kantian framework. Immanuel Kant first established that human reason should be limited in order to accommodate faith. The father of liberal Protestantism, Friedrich Schleiermacher (17681834), built upon Kant's philosophy. He established the idea that consciousness of God can never be possessed as knowledge. Rather than something owned, an individual experiences consciousness of God as a feeling of "utter dependence" on the Divine. ${ }^{8}$ "God-Consciousness" (as Schleiermacher termed it) is deeper than reason. ${ }^{9}$

Schleiermacher's philosophy profoundly impacted the practitioners of liberal theology who followed in his wake. Throughout his career, Cadman frequently referenced Schleiermacher in his written work, drawing freely upon the ideas established by the German theologian. ${ }^{10}$

\footnotetext{
${ }^{7}$ Ibid., 4.

${ }^{8}$ S. Parkes Cadman, Adventure for Happiness (New York: The Macmillan Company, 1935), 296.

${ }^{9}$ For Schleiermacher's view on religious experience see his work, The Christian Faith. H.R. Mackintosh and J.S. Stewart edited the 1999 edition. Gary Dorrien explores the connection between Schleiermacher and nineteenth-century liberal theology in the first volume of The Making of American Theology.

${ }^{10}$ Cadman discussed Schleiermacher in Imagination and Religion (1926). However, the minister's most indepth discussion of the theologian is found in Ambassadors of God (1920), 73-76.
} 
Henry Ward Beecher (1813-1887) contributed a great deal to the advancement of liberal Protestant theology in nineteenth-century America. A Brooklyn Congregational minister and the most popular preacher of his time, Beecher influenced Cadman to the point that, later in life, Cadman's contemporaries often drew comparisons between the two men." Clifford E. Clark, Jr., in his 1978 study of Beecher, argues that Beecher created a "new ethos," "built around a core of religious beliefs that might be labeled romantic Christianity. As espoused by Beecher, romantic Christianity was a religion of the heart, an appeal to the feelings and emotions that replaced the cold, formalistic evangelical theology of the previous generation and accepted the new theories of evolution and biblical criticism .... It was a cheerful and optimistic faith." ${ }^{.12}$ Beecher's mix of liberal Protestantism and Romanticism profoundly affected Cadman's intellectual development. Of the nineteenth-century minister, Cadman, in 1920, wrote, "Competent authorities rank him as the first preacher of his century; I venture to go further and place him at the summit of the sacred oratory of the last two hundred years."13

While imbibing the ideas of these influential thinkers at Richmond College, Cadman married, in October 1888, Lillian Esther Wooding. The ceremony took place in their mutual hometown of Shropshire. Nothing in detail has been written on Lillian Esther Wooding. Hamlin notes that his account of Cadman's life lacks details concerning Mrs. Cadman because, as he explains, "When this story was in preparation she requested that the privacy of the Cadman family circle should not be violated." ${ }^{\prime 4}$ Because the

\footnotetext{
${ }^{11}$ See "Personalities: Dr. S. Parkes Cadman, Preacher, Who Laughs When He is Compared to Beecher," The World's Work, February, 1925, Volume 49.

${ }^{12}$ Clifford E. Clark, Henry Ward Beecher: Spokesman for a Middle-Class America (Chicago: University of Illinois Press, 1978), 3-4.

${ }^{13}$ S. Parkes Cadman, Ambassadors of God (New York: The Macmillan Company, 1920), 80.

${ }^{14}$ Hamlin, S. Parkes Cadman, 61.
} 
accounts of Cadman's life written after 1930 rely heavily on Hamlin's book, there is a dearth of information on Lillian Cadman and the three children the two had together.

Cadman graduated from Richmond College in 1890 and decided to begin his ministry in America rather than in his homeland. Hamlin argues, generically, that Cadman's reason for leaving England stemmed from the minister's love of American history. ${ }^{15}$ More likely, the reason stemmed from a rule within Methodism that prohibited the marriage of student candidates for the ministry. Cadman, who remained silent on the matter, graduated despite his violation of the rule. In a 1928 article, Henry Lunn (18591939), who knew Cadman during his time at Richmond College, asserted that Cadman left England because of the prohibition on student marriages. Lunn writes that, "In consequence of the [marriage] regulation Dr. Cadman left his mother church, British Methodism, to find a wider sphere than could be afforded him in the old country.,16 Coupled with the rule violation was the fact that, while at Richmond, "Bishop John Fletcher Hurst, of the American Methodist Church, had said to young Cadman: 'If you ever come to America I will get you a church." ${ }^{17}$ Regardless of his reasoning, Cadman traveled to New York City in October 1890. Lillian stayed behind in Shropshire until Cadman established himself financially. She would join her husband in 1891.

Cadman's first appointment in the Methodist church was the vacant pulpit at Millbrook Methodist Episcopal Church, Millbrook, New York in 1890. The congregation was small, the pay only $\$ 600$ a year (and then only if he could raise such a sum from his congregation). Undaunted, Cadman approached the Millbrook ministry with vigor.

\footnotetext{
${ }^{15}$ Ibid., 62.

${ }^{16}$ Henry Lunn, "Dr. Cadman: At Home and Abroad," The American Monthly Review of Reviews, January, $1928,60$.

${ }^{17}$ Hamlin, S. Parkes Cadman, 63.
} 
Cadman cut his teeth at the small church, making a name for himself in the surrounding community. In 1893, a better opportunity called and Cadman moved his ministry to the Central Methodist Church at Yonkers. Central Methodist was an important stepping stone in Cadman's career. It was here that he first implemented the question-and-answer session for which he would later become popular. ${ }^{18}$ Cadman spent two formative years in Yonkers before moving on to the Metropolitan Temple, New York City. During his tenure at Metropolitan, Cadman earned the first two of his honorary doctoral degrees. Cadman received Doctorate of Divinity degrees in 1898 from the University of Syracuse and from Wesleyan University (Middleton, Connecticut).

In December 1900, Cadman again shifted his ministry to another church. “The call to the pulpit of the Central Congregational Church of Brooklyn - one of the most famous ministerial posts in all America - came to Dr. Cadman on December 18, 1900," writes Hamlin. ${ }^{19}$ In 1900, Central Congregational was the second largest Congregational church in America. ${ }^{20}$ This move, however, was not only between churches; Cadman switched from the Methodist denomination to Congregationalism. Most biographers go into detail about Cadman's work within the Congregational Church system while remaining silent about the reason Cadman left Methodism. The pulpit Cadman assumed was prestigious, and the autonomous nature of Central Congregational certainly appealed to the strong-minded, opinionated Cadman. But the question remains as to why he made the move. The prestige, Hamlin implies, attracted the ambitious Cadman. A New York Times article from March 10, 1900 entitled "The Rev. Dr. S. Parkes Cadman May Leave

\footnotetext{
${ }^{18}$ Leiper and Staples, Dr. S. Parkes Cadman, 12.

${ }^{19}$ Hamlin, S. Parkes Cadman, 98.

${ }^{20}$ Theodore Louis Trost, Douglas Horton and the Ecumenical Impulse in American Religion (Cambridge, MA: Harvard University Press, 2002), 23.
} 
Methodist Church" answers the question as to why, however. The "Itinerant Rule" of the Methodist church stated that a pastor could not remain with a single congregation for more than five years. The article stated that, "the Rev. Dr. Cadman himself started the Metropolitan work, and he wants to remain in a popular service in this city."21 Cadman wanted to find a permanent position. Although he had moved between several churches up to the point in his life, Cadman did not wish to begin anew every five years for the remainder of his career. The Congregational Church did not have an "Itinerant Rule" and, therefore, offered Cadman the permanent position he desired. ${ }^{22}$

Cadman found Central Congregational to his liking. He spent the remaining thirty-five years of his life and career in service to the church. The opportunity to embark upon an academic life came to Cadman in his early years at Central. In 1908, a council at Wesleyan University offered Cadman the presidency of their institution. However, "Dr. Cadman declined the offer, insisting that he was dedicated to the preaching ministry."23 If Cadman's time at Yonkers and the Metropolitan Temple had been formative, his time at Central Congregational encompassed his greatest work. Cadman's literary career, his radio work, and his ecumenical efforts all took place fully in the years he spent as minister at Central Congregational.

In 1909, Cadman published The Victory of Christmas, the first of his many books. Two years later he published an important work in the rise of liberal Protestantism, Charles Darwin and Other English Thinkers (1911). In this work, Cadman emphasized

\footnotetext{
21 "The Rev. Dr. S. Parkes Cadman May Leave Methodist Church," New York Times, March 10, 1900.

${ }^{22}$ Ibid. The article also stated that Central Congregational was not the only Congregational Church seeking Cadman as a minister. Pilgrim Congregational Church in Harlem also offered Cadman the position. Cadman chose Central Congregational.

${ }^{23}$ Leiper and Staples, Dr. S. Parkes Cadman, 61. Cadman later served as "Acting President" for Adelphi College from 1911-1914.
} 
his liberal roots, maintaining that evolution and Christianity were compatible. The work foreshadowed the public battles fought over evolution between fundamentalist and liberal Protestants following World War I. Cadman's books generally follow one of three formulaic constructions: first is the single sermon published in book form; second is the collection of lectures delivered at seminaries or universities and later published as a single volume; and the third type constitutes Cadman's more-developed works, written as single texts (as opposed to themed lectures) and published as such. The Victory of Christmas (1909) is a sermon; Charles Darwin and Other English Thinkers is a collection of lectures, ${ }^{24}$ and Adventure for Happiness (1935) is an example of a moredeveloped work. Cadman published his most influential book, a collection of lectures, in 1920 as Ambassadors of God. W.L. Watkinson quipped that, because of Cadman's text, "another book on preaching would not be needed for fifty years." 25

From the beginning of Cadman's ministry in 1890 , books that focused on the personality of Jesus flooded the realm of religious publishing. The quest for a biography of Christ started in the Victorian era when a fascination with biography in general preoccupied the minds of many writers and lecturers. This trend influenced Cadman. From the late-nineteenth century onward, writers struggled to adapt the personality of Jesus to popular social trends. In the 1880 s and 1890 s, for instance, Jesus fit the mold of a he-man in the popular strains of a more muscular Christianity. ${ }^{26}$ The manly portrayal of Jesus coincided with the increasing involvement of women in the hierarchy of various

\footnotetext{
${ }^{24}$ The lectures collected in the volume were delivered in Autumn, 1910 at The Brooklyn Institute of Arts and Sciences.

${ }^{25}$ Hamlin, S. Parkes Cadman, 114. Watkinson (1838-1925), served as President of the Wesleyan Methodist Conference in 1897.

${ }^{26}$ If Christ Came to Chicago!: What Would Jesus Do? (1899) by W.T. Stead is an example of this type of literature. Charles M. Sheldon's In His Steps: What Would Jesus Do? (1897), the source of popularity for the phrase "What Would Jesus Do?," inspired Stead's work.
} 
Christian churches. Leaders pushing for female involvement in the church developed a Jesus of their own during the same period. In contrast to the muscular, manly Jesus, women leaders fashioned a feminine Jesus, justifying the idea by noting that only one human had contributed to the genetics of Jesus, and that was a woman. ${ }^{27}$ Regardless, manly Jesus remained popular throughout the Progressive Era and into the $1920 \mathrm{~s}^{28}$ It was in this decade, however, that Jesus took on the personality of an adept businessman.

Bruce Barton's The Man Nobody Knows: A Discovery of Jesus (1925) is largely responsible for popularizing this image. Barton's text cast Jesus as the perfect man of business, and argued that if Jesus had lived in 1920s America, he would have been a capitalist like any other sensible man. Wealth and Christianity have always been strange but willing bedfellows, but Barton made the relationship overt. ${ }^{29}$

Cadman never accepted the popular conceptions of a modified Jesus. Concerning

Barton's Jesus, Cadman, in 1929, wrote,

Primal values are not recognized, as they should be, by Bruce Barton in his widely read volume, The Man Nobody Knows. Its arresting title is scarcely justified in view of the testimony of the Gospels, and of countless souls who in every subsequent age have confessed their indebtedness to Jesus as their Savior and Lord. Nor does Mr. Barton's delineation of the Master accord with the conception of the Evangelists and Apostles of the New Testament. However sympathetic may be his presentation of Jesus as a man of affairs, a typical captain of industry and trade ... possessing resilient physical strength ... this curiously

\footnotetext{
${ }^{27}$ The idea of the feminine Jesus at least dates back to the mystical work of Julian of Norwich entitled Revelations of Divine Love (ca. 1373). Caroline Walker Bynum, in her influential study Jesus as Mother: Studies in the Spirituality of the High Middle Ages (1982), argues that the idea of a feminine Jesus dates back to the patristic writers of Late Antiquity. In Answers to Everyday Questions (179), Cadman confronted Christians who chose to see Jesus as mother. In answer to a query concerning the topic, Cadman answered, "If you believe you should call God "Mother," no law of logic or of religion known to me prevents you." ${ }^{28}$ The Quest of the Historical Jesus (1906) by Albert Schweitzer is another important book from this period. Schweitzer examined the attempts of scholars who tried to construct a biography of Jesus from historical sources. According to Cadman, Schweitzer's argument that Jesus was "absorbed in a wholesale apocalyptism" was "sheer assumption." See S. Parkes Cadman, The Christ of God (New York: The Macmillan Company, 1929), 50.

${ }^{29}$ See Bruce Barton, The Man Nobody Knows (Indianapolis: Bobbs-Merrill, 1925).
} 
mundane figure is a stranger to those who have rightly appraised the portrayals of New Testament literature. ${ }^{30}$

Popular notions of Jesus influenced Cadman in that he consciously rebelled against modifying Christ. Cadman contributed to the field with The Christ of God (1929). In this text, Cadman adhered to information found in the Gospels when discussing the life and personality of Jesus.

Cadman's books are an important part of his legacy. More than any other work he produced, Cadman's writings provide a clear window into his ministry and into the theological constructions of his personal beliefs. However, contemporaries noted that Cadman's greatest work was not in print but in radio. "Dr. Cadman will never be best loved for his books, however well-written they were. He was an orator," argue Leiper and Staples. ${ }^{31}$ Cadman's gift for oratory found a home on American airwaves in the 1920s. Circumstance largely dictated the road he took to radio, however. The opportunity came to him in 1923, three years before the formation of NBC.

Between 1901 and 1923, Cadman had conducted Sunday afternoon services at the Y.M.C.A in Bedford, New York. In 1901, Halsey Hammond, a representative of the National Board of the Y.M.C.A, had invited Cadman to speak at an outdoor service featuring several of New York's most popular ministers (and featuring the accompaniment of a brass band). The service was successful, and for the following two years Bedford hosted a meeting each Sunday afternoon. "Dr. Cadman," Hamlin writes, "took the season's program, and became the speaking backbone of the meetings." 32 After 1903, the program lessened its extravagance, cutting down its number of speakers, and

\footnotetext{
${ }^{30}$ Cadman, Christ of God, 77-78.

31 Leiper and Staples, Dr. S. Parkes Cadman, 17-18.

${ }^{32}$ Hamlin, S. Parkes Cadman, 122.
} 
retained Cadman with the occasional guest speaker. The Sunday afternoon service at Bedford did not decrease in popularity, however. Moving inside the 1,100-seat Bedford auditorium, the service continued to grow with Cadman at the helm for the next twenty years.

In 1923, a representative of station WEAF, New York visited Cadman's Brooklyn home with an offer to install broadcasting equipment at Central Congregational. WEAF wanted to broadcast a religious service. ${ }^{33}$ Cadman did not find the offer appealing and turned it down. The two men agreed, however, to experiment with the idea of a service broadcast from the Y.M.C.A auditorium in Bedford. Cadman preached over the radio for the first time in January $1923 .{ }^{34}$ Early on, Cadman had trouble adjusting to the confines of radio broadcasting. The technology, still in its infancy, could not handle a lot of noise. Cadman often raised his voice, which caused a great deal of static; he often moved away from the microphone, or turned his head from side to side when he spoke, causing his voice to fade in and out. Once, Cadman slammed his Bible on the pulpit to provide an exclamation point for his words. "The audience in the Bedford ' $\mathrm{Y}$ ' listened to the rest of his talk with interest. But the [radio] audience missed more than half of it. When he slammed down the Bible, he had blown out every fuse in the broadcasting outfit. ${ }^{, 35}$ But Cadman eventually adjusted his methods to fit the restrictions of radio preaching so that Edgar DeWitt Jones, writing in 1932, could describe Cadman as the "most effective radio preacher in the land .... Nobody listening in loses a word of his sermons. He speaks with marked clarity as well as fluency. He makes almost constant use of the short sentence.

\footnotetext{
${ }^{33}$ WEAF, originally named WBAY, first broadcast on July 25 , 1922. See Douglas B. Craig, Fireside Politics: Radio and Political Culture in the United States, 1920-1940 (Baltimore: The Johns Hopkins University Press, 2000), 19.

${ }^{34}$ S.W.S, "'Give Truth the Open Field---," The Wireless Age, April, 1923, 27.

${ }^{35}$ Hamlin, S. Parkes Cadman, 126.
} 
His diction is chaste and beautiful, yet he never sacrifices vigor of thought or pungency of expression for mere rhetorical charm.. ${ }^{36}$

Cadman carried on the question-and-answer session he had employed since his time at Yonkers on the WEAF program. According to Henry F. Pringle, Cadman's early services consisted of a half-hour sermon, the performance of several hymns, and close to thirty minutes of questions and answers. ${ }^{37}$ The questions were culled from letters sent in by the program's listeners and were diverse in content. Questions ranged in topic from indepth theological issues concerning the influence of Neoplatonism on modern Christian thought to Cadman's favorite Dickens' character. ${ }^{38}$ As far as the number of listeners to Cadman's program is concerned, the February 1925 issue of The World's Work ${ }^{39}$ profiled Cadman and estimated that "at least 500,000 persons, probably more, hear Dr. Cadman talk through the four broadcasting stations on Sunday afternoons." ${ }^{.40}$ The stations were located in New York, Providence, Boston, and Washington. ${ }^{41}$ Furthermore, the conference secretary of the Bedford services estimated that listeners sent " 2,000 or more letters" to Cadman each week. ${ }^{42}$

Cadman's introduction to newspaper work is connected to the question-andanswer session on WEAF. Theodore Louis Trost explains, "These unrehearsed exchanges were transcribed and published in a newspaper column that appeared in the New York

\footnotetext{
${ }^{36}$ Edgar DeWitt Jones, American Preachers of To-day (Freeport, NY: Books for Libraries Press, 1971), 306.

${ }^{37}$ Henry F. Pringle, Big Frogs (New York: The Vanguard Press, 1928), 63.

${ }^{38}$ See S. Parkes Cadman, Answers to Everyday Questions (New York: The Abingdon Press, 1930).

${ }^{39}$ The World's Work, an American monthly periodical, ran from 1900 until 1932, when it merged with Review of Reviews. Although focused primarily on international rather than domestic issues, the magazine provided several biographical sketches of important contemporary figures in American culture in each issue under the heading of "Personalities."

40 "Personalities: Dr. S. Parkes Cadman, Preacher, Who Laughs When He is Compared to Beecher," The

World's Work, February, 1925, Volume 49, 387.

${ }^{41}$ Ibid.

${ }^{42}$ Ibid.
} 
Herald Tribune. ${ }^{, 43}$ The column, entitled "Dr. Cadman's Daily Column," consisted of several questions sent to Cadman via letter along with the minister's answers to the queries. As of 1928, Cadman's column was "syndicated to eighty other newspapers throughout the country with a total circulation of more than ten million readers a day." In 1930, Cadman published a "best-of" collection of these transcriptions entitled Answers to Everyday Questions.

Cadman was a pioneer of religious broadcasting. But, even in the early 1920s, he was not alone in his utilization of the medium for religious purposes. KDKA, Pittsburgh, credited with the first commercial broadcast in 1920, for example, entered the field of religious broadcasting on January 2, 1921 when the station featured the evening vesper service of Reverend Edwin J. Van Etten of the Calvary Episcopal Church, Pittsburgh. ${ }^{45}$ Aimee Semple McPherson's Foursquare Gospel, rooted in evangelical Pentecostalism, found a receptive and demographically diverse radio audience in the early 1920 s as well. An important religious figure in her time, McPherson, according to her biographer Matthew Avery Sutton, "first experimented with radio in 1922, during a revival meeting in the San Francisco Bay area." ${ }^{46}$ In 1923, McPherson raised \$25,000 to construct the 500-watt Kall Four Square Gospel (KFSG) radio station. The station first aired from Los Angeles in February, 1924 and helped propel McPherson to the status of a "religious

\footnotetext{
${ }^{43}$ Trost, Douglas Horton, 25.

${ }^{44}$ Pringle, Big Frogs, 61.

${ }^{45}$ Spencer J. Mills, Jr., "Radio and Religion," Annals of the American Academy of Political and Social Science, January, 1935, Volume 177, 135. cf. Susan J. Douglas, Listening In: Radio and the American Imagination (Minneapolis: University of Minnesota Press, 2004), 64 and Fortner, Radio, Morality, and Culture, 109. Douglas and Fortner mix up a number of details in their discussions of KDKA's inaugural religious broadcast. For example, Douglas refers to the church as "Calgary" Episcopal rather than "Calvary" Episcopal, and Fortner cites the broadcast date as April 2, 1921 instead of January 2, 1921.

${ }^{46}$ Matthew Avery Sutton, Aimee Semple McPherson and the Resurrection of Christian America (Cambridge, MA: Harvard University Press, 2007), 78.
} 
celebrity." ${ }^{47}$ Harry Emerson Fosdick, too, began his radio career in this period. Fosdick, Northern Baptist minister and professor at Union Seminary in New York, first spoke over the airwaves at the RCA-owned station WJZ, New York in $1924 .^{48}$ When WJZ became a part of the NBC Blue Network in 1927, Fosdick became the "every-Sunday star" of National Vespers, a program which "gained him an enormous national following" and ran for nineteen years. ${ }^{49}$ Fosdick was not as colorful as McPherson. Father Charles E. Coughlin, another early religious radio orator, however, rivaled McPherson's ability to attract attention. Coughlin broadcast from his Shrine of the Little Flower in Royal Oak, Michigan beginning in 1926. Coughlin's first program was aimed at children and contained none of the fiery rhetoric for which he would come to be known (the program on WJR, Detroit was known as "The Children's Hour"). WJR was part of the CBS network of stations, but Coughlin's program, aimed at an adult audience after 1927, was not broadcast over the national network until $1930 .^{50}$

In 1926, after Cadman had been on WEAF for three years, the station became the flagship station of the new broadcasting network, the National Broadcasting Company (NBC). NBC developed out of a partnership between General Electric (GE) and the Radio Corporation of America (RCA), and operated as two networks, NBC Red and NBC Blue, until 1943. Cadman benefited from the growing fortune of WEAF (soon to be WNBC). Cadman spoke over the NBC network from its establishment in 1926 until his death in 1936. From 1926 until 1928, he conducted services at the Bedford Y.M.C.A.

\footnotetext{
${ }^{47}$ Ibid., $3,79$.

${ }^{48} \mathrm{WJZ}$, in 1927, became the flagship station for NBC Blue Network. After NBC Blue Network became the American Broadcasting Company (ABC) in 1943, WJZ changed its name to WABC.

${ }^{49}$ Gary Dorrien, The Making of American Liberal Theology: Idealism, Realism, and Modernity, 1900-1950 (Louisville, KY: Westminster John Knox Press, 2003), 384.

${ }^{50}$ Donald Warren, Radio Priest: Charles Coughlin, the Father of Hate Radio (New York: The Free Press, 1996), 23-24.
} 
auditorium. After 1928, Cadman moved to the Cathedral Studio at NBC. ${ }^{51}$ From there, Cadman preached under the heading of The National Radio Pulpit, an umbrella title for a plethora of different liberal Protestant speakers. Generally, a non-denominational sermon given by the show's Sunday afternoon host was the central focus of the program.

Cadman, along with Harry Emerson Fosdick, and, later, Ralph W. Sockman hosted the program at different times. Each constituted a different Protestant denominationCadman was Congregationalist; Fosdick was Northern Baptist; and Sockman was United Methodist. It is significant, but not surprising, that NBC favored liberal Protestant speakers on The National Radio Pulpit as opposed to speakers affiliated with fundamentalism. The program constituted public service time, a licensing requirement under the stipulations of the Radio Act of 1927. In other words, because the program was considered a public service, the speakers who worked under the umbrella of The National Radio Pulpit did not have to pay for airtime as did fundamentalist preachers such as Walter A. Maier. ${ }^{52}$ The sustaining program (or public service program) constituted one of two models for programs in network broadcasting. Sustaining programs, as Benjamin explains, "were those shows developed and aired by the networks or stations themselves and for which the broadcaster received no revenue. Often, these shows ... were carried primarily for their prestige or goodwill value to the broadcaster." The commercial program, which sought a sponsor and, ideally, generated revenue, was the second type of program. In 1931, Cadman moved from the auspices of The National Radio Pulpit and conducted services on a program simply entitled Dr. S. Parkes Cadman. This particular

\footnotetext{
${ }^{51}$ Hamlin, S. Parkes Cadman, 129.

${ }^{52}$ Tona Hangen, "Man of the Hour: Walter A. Maier and Religion by Radio on the Lutheran Hour," in Radio Reader: Essays in the Cultural History of Radio, ed. Michele Hilmes et al. (New York: Routlege, 2002).
} 
program aired each Sunday from 4:00 p.m. until 5:00 p.m. over the NBC airwaves, and was carried by an impressive forty-three network stations. ${ }^{53}$ In contrast, Fosdick's National Vespers aired from 5:00 p.m. until 6:00 p.m., in 1931, over twenty-eight NBC stations. $^{54}$

The wide audience Cadman accessed through radio convinced the minister that the medium was worth his energy. If properly utilized, he believed, the radio could prove to be a valuable tool for spreading Christianity. In a Federal Council Bulletin from October 1928, Cadman appeared confident about radio's possibilities. Cadman told the interviewer, "Radio, the latest marvel of science, has shown that, rightly used, science is still the handmaiden of religion." 55 In addition, the large number of letters Cadman's program received encouraged the minister. He was especially impressed by the geographical diversity of those who wrote to him. NBC bragged in 1928 that Cadman's voice, from the new set-up at the Cathedral Studio in New York, would reach "every state in the Union and also to Cuba, Mexico and Canada, and, under favorable conditions, to the far ends of the earth." 56 In 1930, a radiogram sent by Commander Richard E. Byrd from the South Pole, thanking Cadman for a sermon he had been able to listen to from so far away, rewarded NBC's faith. ${ }^{57}$

The rise of American radio coincided with the public battle between fundamentalist and liberal/mainstream Protestants. Although the roots for this Protestant divide are in the nineteenth century, the division deepened in the Progressive Era and

\footnotetext{
53 "Religion: Air Worship," Time, February 9, 1931.

${ }^{54}$ Ibid.

55 "Dr. Cadman to Become 'International Minister of the Air,"' Federal Council Bulletin, October, 1928, 15.

${ }^{56}$ Ibid.

${ }^{57}$ Hamlin, S. Parkes Cadman, 129.
} 
accelerated in the years following World War I. The difference between liberal and fundamentalist Protestants in a nutshell is that fundamentalist Protestants believe that Christianity is immutable and that strict adherence to the tenets of the Bible is necessary for salvation. Religion should not adapt to modes of thought simply because they are deemed modern. Liberal Protestants believe that certain aspects of Christianity are mutable and that Christian thought should change and adapt with the times. Liberal Protestants, for example, believe that science and religion are compatible. During the interwar period, the liberal view was also labeled Modernism. ${ }^{58}$

The Scopes Trial, in which the state of Tennessee charged John Scopes, a high school biology teacher in Dayton, Tennessee, with violating a state law prohibiting the teaching of Darwinian evolution, proved the most public battlefield in the 1920 s for the two sides of Protestantism. John Scopes lost the trial, but fundamentalism received a black-eye from the media in 1925 and in the years immediately following. William Jennings Bryan, who assumed the voice of fundamentalism at the trial and proclaimed himself an expert on all things biblical, suffered humiliation under the cross-examination of the agnostic Clarence Darrow.

During the most intense period of this rift (1924-1928), Cadman served as president of the Federal Council of the Churches of Christ in America (FCCCA). Cadman succeeded Robert E. Speer in December 1924, when the FCCCA delegates elected him president at the Atlanta, Georgia conference. Founded in 1908, the FCCCA stemmed from the Inter-Church Conference on Federation held at Carnegie Hall in November 1905 and initially included thirty-three denominations. The primary function of the FCCCA

\footnotetext{
${ }^{58}$ For further discussion of the differences between fundamentalist and liberal Protestants, see Martin E. Marty, Modern American Religion Volume 2: The Noise of Conflict, 1919-1941 (Chicago: The University of Chicago Press, 1991), 155-164.
} 
was to unite the Protestant churches in federal union. In contrast to organic union, which is the full unification of churches under one ruling body, federal union consists of churches coming together while retaining individual autonomy. The FCCCA adopted a constitution in 1908 that made explicit the council's five major intentions:

(1) To express the fellowship and catholic unity of the Christian Church; (2) to bring the Christian bodies of America into united service for Christ and the world; (3) to encourage devotional fellowship and mutual counsel concerning the spiritual life and religious activities of the Churches; (4) to secure a larger combined influence for the Churches of Christ in all matters affecting the moral and social condition of the people, so as to promote the application of the law of Christ in every relation of human life; and (5) to assist in the organization of local branches of the Federal Council to promote its aim in their communities. ${ }^{59}$

As president, Cadman expanded upon the mission of the FCCCA, seeking the ultimate union of all Christian churches. In Cadman's "official sermon" to the council after his election as president he prophesized that, "all forms of Protestantism and Roman and Greek Catholicism would "be sublimated in one great faith." Protestantism remained a prerequisite, but after the 1920s, Protestant union came to be seen as a stepping stone for further Christian unity.

Cadman also pushed the explicit social gospel tendencies of the FCCCA. By the early-twentieth century, the social gospel was firmly established in American theology. In 1908, the delegates of the FCCCA, in addition to adopting a constitution, drafted "The Social Creed of the Churches." ${ }^{, 61}$ The document maintained that the application of Christian ethics could cure the social problems prevalent in the United States. Gary Dorrien argues that the social gospel tendency of the FCCCA was a key function through

\footnotetext{
${ }^{59}$ Don Herbert Yoder, "Christian Unity in Nineteenth-Century America," in A History of the Ecumenical Movement, 1517-1948, ed. Ruth Rouse et al. (Philadelphia: The Westminster Press, 1967), 257.

60 "Federal Council," Time, December 15, 1924.

$<$ http://www.time.com/time/magazine/article/0,9171,728189,00.html>

${ }^{61}$ Walter Rauschenbusch (1861-1918), an important theologian of the Protestant social gospel, helped compose the document.
} 
the organization's early history. "The early Federal Council functioned, in effect, as a kind of laboratory for social gospel ideas that infiltrated the churches and seminaries," Dorrien writes. "It placed divisive Christian doctrines off-limits and sought to advance common social goals. ${ }^{, 62}$ Cadman sought to keep the social ills of the United States a matter of urgency for the FCCCA. In 1929, Cadman looked back on the decade with satisfaction as far as the social gospel was concerned:

The Social Creed ... contemplates the establishment of those conditions in society which secure equal and speedy justice, and the full and untrammeled exercise of their legitimate rights for all members of the human race, wherever found. Truly the social conscience of institutional religion has been amazingly revived, educated and disciplined during the past decade. In the United States that conscience is increasingly sensitive concerning non-social methods and practices which afflict the well-being of the people. ${ }^{63}$

When the council elected Francis J. McConnell (Methodist) the FCCCA president in December 1928, council delegates appointed Cadman "Radio Minister of the FCCCA." The first to serve in the office, Cadman held it for the remainder of his life. In the December 17, 1928 issue, Time reported that the FCCCA delegates offered Cadman $\$ 25,000$ a year to continue to preach over the radio as a representative of the council. Thinking the proposed salary exorbitant, Cadman turned down the offer. In light of this, the FCCCA delegates "installed for Dr. Cadman the unique office of Radio Minister, carrying no salary, which he accepted." ${ }^{\prime 64}$ Cadman delivered more than five-hundred radio addresses in his lifetime; he received pay for none of them. ${ }^{65}$

Cadman's association with the FCCCA, both as president and "radio minister," is a significant link to his success on radio after WEAF became a part of the NBC network.

\footnotetext{
${ }^{62}$ Dorrien, The Making of American Liberal Theology, 107.

${ }^{63}$ Cadman, The Christ of God, 145-146.

64 "Religion: Federal Council," Time, December 17, 1928.

65 "Died: S. Parkes Cadman," Newsweek, July 18, 1936, Vol. 8, 29.
} 
Benjamin demonstrates that NBC favored speakers associated with the FCCCA as opposed to speakers with fundamentalist affiliation. ${ }^{66}$ The fact that Charles F.

MacFarland represented Protestantism on NBC's Committee on Religious Activities for the NBC Advisory Council from 1926 to 1931 is evidence of this favoritism. At the same time, MacFarland served as social secretary for the FCCCA - a position he held from $1912-1931 .^{67}$

Cadman used his success on radio to further his vision of Christian ecumenism. Cadman discussed the matter in his sermons and he touched on the matter frequently in his question-and-answer session. Cadman also participated in a number of councils in the late 1920 s and early 1930 s that sought to foster ecumenical activity. "From 1920 on - and with increasing frequency - the years were marked by instances of [Cadman's] involvement in ecumenical affairs," write Leiper and Staples. "The greater number of these had to do with the agencies intimately related to the founding of the World Council of Churches; i.e. The Federal Council of Churches, the Universal Christian Council for Life and Work, and the World Conference on Faith and Order."

Despite the public schism between fundamentalist and liberal Protestants, a strong ecumenical current existed in American Christianity during the interwar years. Cadman was not alone in his goal of attaining Christian unity. The Life and Work movement is an example. Officially commencing in 1925 with the Stockholm Conference on Life and Work, the Life and Work Movement was an offshoot of the World Missionary

\footnotetext{
${ }^{66}$ Louise M. Benjamin, The NBC Advisory Council and Radio Programming, 1926-1945 (Carbondale, IL: Southern Illinois University Press, 2009), 50.

${ }^{67}$ Ibid., 17-18.

${ }^{68}$ Leiper and Staples, Dr. S. Parkes Cadman, 35.
} 
Conference at Edinburgh, Scotland in 1910. "The Edinburgh Conference spawned several new groups as it came to a close," Trost explains.

Some participants who were inspired to continue with cooperative missionary work founded the International Missionary Council. Other participants, who wanted to organize concerted Christian action in the social sphere, founded the Life and Work movement. Participants who wanted to explore the taboo subjects of doctrinal differences and ecclesiastical union founded the Faith and Order movement. $^{69}$

Cadman's address at the 1925 Life and Work conference, "Methods of Co-operation and Federative Efforts," won him acclaim and helped get him elected president of the American chapter of the Universal Christian Council for Life and Work. Cadman also delivered an address, "The Nature and Function of the Church," at the first Conference on Faith and Order in 1927. For the remainder of his life, Cadman participated in ecumenical councils in America and abroad. Prominent examples include the Conference of Faith and Order at Murren, Switzerland (1930); The World Alliance (1931); The Modern Churchman's Conference (1931); and the Life and Work sessions in Denmark and Yugoslavia (1934).

Although Cadman continued to preach over the radio and to participate in ecumenical conferences, his written output slowed with the onset of the Great Depression. When the economy began its downward spiral in the fall of 1929, Cadman, approaching his sixty-fifth birthday, had spent nearly forty years as a minister in America. In 1929, he published two books, The Christ of God and Peace. Two more books followed in 1930, Answers to Everyday Questions and Imagination. Producing four books in two years seems prolific, but the number is deceiving. The Christ of God is a collection of lectures; Peace is seventy-one pages long; Answers was culled from radio

${ }^{69}$ Trost, Douglas Horton, 38. 
transcriptions dating back to 1925; and Imagination is eighty-seven pages long. After 1930 , in the six-year span preceding his death, Cadman published only three books. ${ }^{70}$ During this time, however, Cadman maintained a steady presence on NBC stations; his program, Dr. S. Parkes Cadman, ran until 1936. Cadman dealt with the troubles of economic depression in his last major written work, Adventure for Happiness (1935). In this text, Cadman emphasized the Romantic tendencies of his liberal theology, arguing that individual happiness can be found through several avenues, none of which is exclusive and all of which begin within the mind.

On July 5, 1936, after the second of two services he had given that Sunday, Cadman collapsed in Plattsburg, New York. After being rushed to Champlain Valley Hospital, it was determined that he had suffered a ruptured appendix. ${ }^{71}$ As Leiper and Staples write, "Since antibiotics were then unknown, there was little hope of recovery."72 Cadman held on with characteristic strength for seven more days. On July 12 at 1:22 p.m., however, the "first of the radio preachers," as the New York Times dubbed him, slipped into a coma and died - a direct result of peritonitis, which had set in after the initial rupture of his appendix. ${ }^{73}$ Cadman's funeral took place at Central Congregational Church. Bishop Francis J. McConnell, the man who succeeded Cadman as president of the FCCCA, conducted the services and preached a sermon. For several years after Cadman's death, various memorial dinners and services were held for the minister in New York. As late as 1941, the Federal Council Bulletin reported that "On December 18

\footnotetext{
${ }^{70}$ The Parables of Jesus (1931), The Prophets of Israel (1933), and Adventure for Happiness (1935).

71 "S. Parkes Cadman Dies in Coma at 71; Brooklyn Pastor, First of the Radio Preachers, Succumbs to Peritonitis in Plattsburg," New York Times, July 13, 1936.

${ }^{72}$ Leiper and Staples, Dr. S. Parkes Cadman, 33.

73 "S. Parkes Cadman Dies in Coma at 71; Brooklyn Pastor, First of the Radio Preachers, Succumbs to Peritonitis in Plattsburg," New York Times, July 13, 1936.
} 
a city-wide memorial service in honor of the late Dr. S. Parkes Cadman will be held in Brooklyn, N. Y., at the Brooklyn Academy of Music." 74

Not only was Cadman given the accolades he rightly deserved after his death, he received recognition for his influential work during his lifetime. For example, in 1925, a Christian Century poll revealed the twenty-five leading preachers in America. Leiper and Staples explain that, "Ballots were sent to ninety thousand ministers of all denominations. ${ }^{, 75}$ Of the twenty-five ministers named, voters ranked Cadman first. ${ }^{76}$ In the same year, Church Management conducted a similar poll with Cadman coming in at number one. ${ }^{77}$ In 1926, in recognition of his twenty-five years of service at Central Congregational, the members of Cadman's church rewarded him with a gift of $\$ 25,000-$ $\$ 1,000$ for every year of service. ${ }^{78}$ In the 1920 s and 1930 s, Cadman's popularity was astounding. In 1928, Henry F. Pringle wrote that, "His name is known, from coast to coast, in every household that reads newspapers or twirls the knobs of a radio set." ${ }^{, 79}$ In addition, two United States Presidents, Coolidge and Hoover, invited Cadman to personal conferences at the White House. ${ }^{80}$

Cadman was an influential thinker as well as a popular religious figure in his time. The content of his writings and oratory are important in the development of American theology. The following chapters analyze Cadman's body of work in order to explain the relationship between imagination, popular theology, and ecumenism in his

\footnotetext{
74 "Cadman Memorial Service," Federal Council Bulletin, November, 1941, 13. Cadman's birthday was December 18.

${ }^{75}$ Leiper and Staples, Dr. S. Parkes Cadman, 18.

76 "Peers of the American Pulpit," Christian Century, January 8, 1925, 54-55.

${ }^{77}$ Leiper and Staples, Dr. S. Parkes Cadman, 62.

${ }^{78}$ As of 1923 , according to Pringle, Cadman's salary as minister of Central Congregational was $\$ 12,000$ per year.

${ }_{79}$ Pringle, Big Frogs, 60.

${ }^{80}$ Leiper and Staples, Dr. S. Parkes Cadman, 19.
} 
ministry. Cadman's utilization of popular media and his approach to Christian ecumenism are tied to his complex theory of imagination. Cadman wrote two books on imagination, in 1926 and 1930, and the topic, in general, formed a subtext for most of his interwar writings. To understand Cadman's thoughts on popular theology and ecumenism, it is necessary to understand his thoughts about imagination and its place in the lives of individual Christian adherents. 


\section{CHAPTER II:}

\section{S. PARKES CADMAN'S THEORY OF IMAGINATION}

Cadman lived a full and diverse life. He left behind a body of oratory and writing that, despite its near absence from the historical record, is unique in Christian thought. Throughout his career, Cadman stressed that he was a pastor first and a thinker second. As a public religious figure, he never labeled himself a theologian. However, in the midst of his career as a pastor, Cadman developed several threads of religious thinking that are original to American theology. Cadman was serious when he described himself as a pastor first, but that did not diminish the thought he put into what he felt were urgent theological problems. Cadman's most inspired contribution to theology, and one that greatly influenced his approach to Christian ecumenism, was his theory of imagination.

Cadman defined imagination as the mental function that processes exterior phenomena and translates those phenomena into accessible mental images. Imagination is "the faculty of forming images in the mind," Cadman stated plainly. Imagination becomes religious imagination when it is applied to matters of religion. Rather than a stand-alone category, religious imagination is one of the many possible applications of imagination. Memory, for Cadman, is an extension of imagination, constituting the body of mental images associated with the past experience of an individual and the history of

\footnotetext{
${ }^{1}$ S. Parkes Cadman, Imagination (New York: E.P Dutton \& Co., Inc., 1930), 7.
} 
mankind. Cadman developed his theory of imagination in two seminal works:

Imagination and Religion (1926) and Imagination (1930). The first is a collection of lectures originally delivered at Vanderbilt University in 1924. The second text is a short work, eighty-seven pages, in which Cadman reiterated the main themes of Imagination and Religion, but devoted more time to the role of imagination in secular life. Cadman's theory of imagination spans the corpus of his work and, therefore, threads from writings other than Imagination and Religion and Imagination are helpful. For example, Cadman's 1912 sermon The Religious Uses of Memory is a useful supplement for understanding Cadman's thoughts on the matter of imagination.

Cadman's theory of imagination set him apart from contemporary religious practitioners and constitutes an original contribution to American theology. Quite simply, Cadman was the only religious figure writing on imagination in the 1920s. In the bibliography of Imagination and Religion, Cadman cited four studies on imagination, only one of which covered religious imagination: Imagination and Its Wonders (1899) by Arthur Lovell; The Religious Use of Imagination (1901) by E.H. Johnson; The World as Imagination (1916) by E. Douglas Fawcett; and Imagination and its Place in Education (1920) by Edwin A. Kirkpatrick. ${ }^{2}$ Johnson's The Religious Use of Imagination is the only twentieth-century text on religious imagination that preceded Cadman's Imagination and Religion. ${ }^{3}$ Johnson, like Cadman, argued that imagination has a role to play in religious life because the average Christian finds imagination accessible. "The commonplace Christian of any period is the precise exponent of what our religion is accomplishing for

\footnotetext{
${ }^{2}$ S. Parkes Cadman, Imagination and Religion (New York: The Macmillan Company, 1926), 201-202.

${ }^{3}$ Don M. Aycock, "Religious Imagination in Twentieth Century American Theology: A Study of Four Selected Figures" (ThD dissertation, New Orleans Baptist Theological Seminary, 1986), 6.
} 
that period," Johnson wrote. ${ }^{4}$ Imagination, for Johnson, is the foremost "guide to truth and duty." Unlike Cadman's texts, however, The Religious Use of Imagination does not cover Christian ecumenism and, overall, lacks an emphasis on imagination's creative function.

Cadman's unique ideas about imagination in religious life are tied to his background in liberal theology and Romanticism. Cadman received his theological training in the latter-half of the $1880 \mathrm{~s}$, a time of upswing for liberal Protestantism. Since the time of Schleiermacher (1768-1834), liberal theology had developed along the lines of a central tenet: the comprehension of God, beyond the power of human reason, is accessible to human feeling, a deeper reservoir than reason. Human feeling, in this instance, refers to human emotion and intellectual self-consciousness. This liberal idea prevailed in institutions of higher learning during the 1880 s and 1890 s. Cadman believed that feeling is the basis of religious experience. In the nineteenth century, however, there was ambiguity about what "human feeling" encompasses. Over time, Cadman came to believe that imagination is a distinct aspect of human feeling. Romanticism heavily influenced this idea.

In the nineteenth century, Romanticism influenced literature, the visual arts, and music, but it also played an influential role in the development of theology. As a wideranging reader, Cadman encountered Romantic ideas through prose and poetry such as William Wordsworth's "Intimations of Immortality." In Romanticism and Transcendence: Wordsworth, Coleridge, and the Religious Imagination (2003), J. Robert Barth argues that, in Romanticism, "imagination is of its very nature a religious act [...]

\footnotetext{
${ }^{4}$ E.H. Johnson, The Religious Use of Imagination (New York: Silver, Burdett \& Company, 1901), 220.

${ }^{5}$ Ibid., vi.

${ }^{6}$ Cadman discussed the religious imagination of Wordsworth in Imagination and Religion (1926), 63.
} 
Imagination is founded upon an act of faith - faith in the ability of the human mind to attain something approximating truth, and ultimately faith in a divine empowering source." Cadman's theory of imagination developed in accordance with the Romantic view of imagination. Throughout his career, Cadman carried the tenets of liberal theology and Romanticism with him and used those traditions in formulating his idea of what imagination is and what it can do for an individual.

The Religious Uses of Memory (1912) is Cadman's earliest published work featuring a discussion of imagination. The sermon, originally delivered at Central Congregational, is based on Deuteronomy VIII, Verse II: “And thou shalt remember all the way which Jehovah thy God hath led thee." In 1912, Cadman had been at Central Congregational for eleven years. At this point in his ministry he had yet to fully develop his ideas concerning the power of imagination. However, several passages in the sermon set the stage for what he would later develop into a more comprehensive philosophy. Memory, for Cadman, is connected to imagination and he spoke of the two functions interchangeably. In 1930, he stressed this point with clarity, writing that imagination and memory not only interact, they are one. ${ }^{8}$

In the sermon, Cadman made clear that imagination plays a central role in epistemology. Imagination and memory are the superior attributes of the mind because without their function, principles of the intellect would be "nothing except momentary sensations which, like the foam-flecks on the wave, are lost as soon as found." A proper memory, an ideal Cadman failed to elaborate on, improves the religious life of an

\footnotetext{
${ }^{7}$ J. Robert Barth, Romanticism and Transcendence: Wordsworth, Coleridge, and the Religious Imagination (Columbia, MO: University of Missouri Press, 2003), 1.

${ }^{8}$ Cadman, Imagination, 61.

${ }^{9}$ S. Parkes Cadman, The Religious Uses of Memory (Boston: The Pilgrim Press, 1912), 16.
} 
individual by providing a firm foundation for the establishment of faith. Memory, for Cadman, constitutes more than individual past experience; it also encompasses individual knowledge of history. An individual must observe their own life and the history that preceded them in order to obtain the materials for building a strong faith. Memory, therefore, serves as a foundation upon which the essentials for a religious life can grow. Cadman argued that imagining past experience influences how an individual lives in the present and how an individual approaches life in the future because faith in God grows from an individual's reservoir of memories. Cadman expanded upon this belief throughout the remainder of his career.

Imagination and Religion (1926) and Imagination (1930), because of their intertwined arguments, deserve to be analyzed in unison. Although two books, the texts run together; Imagination picks up the threads of the 1926 collection of lectures. In the initial lecture of Imagination and Religion, Cadman laid out what he believed to be the three functions of imagination. These three functions form the basis of his theory of imagination. First, imagination allows the individual to reproduce the past. Reproduction of the past is tied to memory; the two mental functions act as one. Second, imagination enables the individual to "vivify" the present. In this function, imagination interacts with phenomena encountered by the external senses. Cadman used the term "vivify" to connote that imagining the present brought the exterior world to life in the mind. Third, imagination is the creative faculty of the mind. Imagination is "creative in that it originates ... ideas." $"$ The first two functions, Cadman argued, provide the foundation for the creative function of imagination. Cadman theorized that, through the three functions of imagination, the average person can make sense of the Divine by identifying

${ }^{10}$ Cadman, Imagination and Religion, 33. 
the "good" in past experience and mankind's history; the individual can, then, come into direct contact with the Divine by translating religious language that is encountered in the present, whether spoken or written, into mental images; and lastly, through the faculty of creative imagination, an individual can use the connection to the Divine to produce positive religious activity in the outer world.

Imagination allows an individual to mentally reproduce past experience and to envision historical events and/or actions. The function of memory and imagination, therefore, is twofold: on one level memory and imagination involve the mental images of reproduced individual past experience; on another level, memory and imagination involve the replication of historical events or actions, whether or not an individual person was directly related to or directly witnessed the happenings in question. Throughout his works, Cadman hinted at but never developed a theory of collective memory that pulses in the human mind; nor did his conception follow the psychological theories of Jung and others. Collective memory, because it encompasses all aspects of history, depends on individual knowledge. In this sense, collective memory is a relative term. An individual must be familiar with an aspect of history for that aspect of history to be a part of their collective memory. The primary importance of this function of imagination is that reproducing certain aspects of the past allows for an interpretation of the Divine. "Memory is indissolubly joined to imagination," Cadman wrote, "and in its finest replica, history, these two powers unite in drawing an outline on a spacious canvas of the lineaments of the Creator, creation and the human race. The heart's discernment of a Divine Order in the past is achieved by imagination and experience in combination."11

\footnotetext{
"Ibid., 24.
} 
Memory constructs a well of information and resources from which the religious individual can draw, and from which he or she can make sense of the Divine. ${ }^{12}$ Cadman's argument in Imagination and Religion built upon the ideas he proposed in The Religious Uses of Memory. In the 1912 sermon, Cadman argued that memory serves as a foundation upon which an individual can build a strong faith in God. In the same sense, an individual can use memory to make sense of the Divine. Imagination, through mental replication of past experience and history, communicates aspects of the Divine that are present in the material world (Cadman referred to these aspects as lineaments or characteristic features) to an individual. According to Cadman, characteristic features of the Divine that are available to the individual include anything positive in either individual past experience or historical events. The Divine, for Cadman, is present in the things that are considered "good." Throughout his work, Cadman remained vague on what "good" entails. Avoiding a strict definition may have been intentional. Cadman communicated his ideas to a wide audience and, therefore, leaving the meaning of what is "good" vague may have proved more inclusive than a definite concept. In other words, the aspects of the Divine present in past experience and historical events are open to interpretation.

For Cadman, identifying the "good" in past experience and historical events brings the Divine into focus. When Cadman spoke of "making sense" of the Divine, he referred to the act of knowing the Divine in its effects, establishing the Divine's

\footnotetext{
${ }^{12}$ The idea of memory serving as a "transmitter" of the divine reflects the influence of Christian Neoplatonism on Cadman's theology. In Answers to Everyday Questions, he addressed Neoplatonism as it appeared in the writings of Plotinus. It is clear that these tenets influenced his conception of memory. The art of memory in the work of the Neoplatonic thinker Giordano Bruno (1548-1600) is exemplary. Frances Yates, in Giordano Bruno and the Hermetic Tradition (1964), argues that the art of memory found in Bruno's worldview constitutes a Hermetic art that enabled thinkers to envision the universe from within. Cadman employed a similar idea to that found in Bruno's writings. Memory allows the individual to make sense of the Divine for Cadman and Bruno.
} 
immaterial contours in a material world. In this sense, memory and imagination, for Cadman, carry a symbolic connotation. The "good" in the past represents the Divine in the present. History as symbolism played a significant role in Cadman's theory of imagination. In Cadman's view, symbolism conveys "impalpable experiences to the mind and heart." 13

Medieval Europe was Cadman's favorite period from which to draw. He was not alone in this during the interwar years. According to Reverend Elizabeth Ann Eliot, in her work The Crowned Knot of Fire: A Study of the Influence of Medieval Symbolism on Modern Poetry (1980), utilizing medieval history as symbolism in literature was commonplace during the early decades of the twentieth century. As Eliot explains, using medieval history was a remnant of Romanticism that persisted following World War I. Keats and Shelley employed medieval history as symbolism in their poetry and the practice remained popular through poets such as T.S. Eliot and Ezra Pound. ${ }^{14}$ Cadman utilized medieval history as symbolism in his theology. For example, Cadman called upon the medieval idea of a united "Christendom" in Christianity and the State (1924). Medieval kingdoms and principalities that identified Christ as a universal ruler represent, in Cadman's view, the many Christian denominations that seek to remove themselves from the oppressive weight of sectarianism. ${ }^{15}$ Medieval Christendom, too, represents the possibility of unity in modern Christianity. By arguing that finding the "good" in past experience and in history allows recognition of the Divine, Cadman urged individuals to establish a solid foundation for their faith. Although Cadman focused on the past in this

\footnotetext{
${ }^{13}$ Cadman, Imagination and Religion, 119.

${ }^{14}$ Elizabeth Ann Eliot, The Crowned Knot of Fire: A Study of the Influence of Medieval Symbolism on Modern Poetry (New York: Vantage Press, 1980), 100-107.

${ }^{15}$ S. Parkes Cadman, Christianity and the State (New York: The Macmillan Company, 1924), 229.
} 
regard, he did not reject modernity. Rather, he utilized the past in the name of the modern. Cadman remained focused on the future of Christianity in that he argued that utilizing the past is foundational for the progression of Christianity.

The ability to "vivify" the present constitutes Cadman's second function of imagination. In this function, imagination "connects the subject to the object, and the beholder with the vision. It supplies the foregrounds of religion here and those of its more perfect developments hereafter." ${ }^{\text {16 }}$ Vivification of the present allows an individual to come into direct contact with the Divine by allowing an individual to envision the Divine with the mind's eye. Whereas imagination coupled with memory allows an individual to make sense of the Divine, imagination's vivification of the present allows an individual to directly know the Divine. Cadman recognized that imagination had to interact with the outer world of the senses if the mental function was to avoid the label of irrelevancy. Imagination had to establish a concrete connection to present reality. In Imagination, Cadman argued that,

instantaneous contacts of the imagination through the senses are a commentary on the truth that 'man does not live by bread alone.' His soul's tentacles bind him to his multiform environment.... Everything in the vast panorama he observes with widely different degrees of appraisal is subservient to his inward growth and the enrichment of his knowledge [...] By his imagination of things seen he feeds on those unseen. ${ }^{17}$

Not only does the present give relevancy to imagination, it provides the materials with which a religious individual needs to function. "Imagination of things seen" allows the individual to "feed" on things unseen. "Things seen" provide the material for individuals imagining the Divine. By inwardly harmonizing "outwardly divergent phenomena" the

\footnotetext{
${ }^{16}$ Cadman, Imagination and Religion, 25.

${ }^{17}$ Cadman, Imagination, 19-20.
} 
individual opens the "mind's eye" to the Divine. ${ }^{18}$ Not all "outwardly divergent phenomena" help to open the mind's eye. For example, decadent literature such as that produced by D.H. Lawrence serves to close the mind's eye rather than to open it. ${ }^{19}$ Therefore, Cadman emphasized that religious language, more than any other phenomenon available to the external senses, connects individuals to the Divine.

Vivification of the present, Cadman argued, is best experienced through the language of religion. Religious language primarily takes two forms: that of the biblical text and that of the sermon, whether written or spoken. In both forms, the religious adherent comes into contact with language. Religious language is in the present; it is concrete, tangible. Whether read or heard, the language of religion, Cadman argued, translates into mental images, and therefore enables the individual to experience the Divine in a direct manner through the mind's eye. By sparking the imagination, the Word is animated ("vivified") and becomes flesh in the individual's mind. Language makes the Divine tangible to an individual's senses. The translation of religious language into mental images constituted a manner in which Cadman felt he could give listeners and readers a link to what is tangible in the Divine: the process of creation. ${ }^{20}$ "Of course the term creative is used here in its secondary sense," Cadman wrote. "Given the right materials to work with, the competent imagination proceeds to weave them into new combinations and forms. ${ }^{21}$ Cadman believed that the language of religion provides the materials for the religious imagination to come into contact with the Divine. This type of

\footnotetext{
${ }^{18}$ Cadman, Imagination and Religion, 24.

${ }^{19}$ Ibid., 87.

${ }^{20}$ Cadman's emphasis on imagination did not please all Christians during the interwar years. For example, fundamentalist author Eric $\mathbb{C}$. Malte, looking back on Cadman in 1938, referred to Cadman's radio work as "pagan discourses." See Eric C. Malte, "Radio's Account with Religion," Cresset, August, 1938, 12.

${ }^{21}$ Cadman, Imagination and Religion, 42.
} 
thinking is in line with the liberal idea that knowledge of God, although not accessible to human reason, is accessible to human feeling. Cadman argued that "feeling" encompasses the mental function of imagination. Reproduction of the past allows an individual to make sense of the Divine; and religious language, the immediate contact with which is always in the present, allows an individual to directly know the Divine.

The third function of imagination, creativity, transcends time, touching both past and present, and builds upon the first two functions. Most significant in regard to Cadman's ideas about what imagination can accomplish, creative imagination has the power to develop new constructions from existing data. The primary importance of imagination's creative ability is that creative imagination, if properly controlled and guided, enables positive religious activity in the outer world. Ideally, for Cadman, an individual inspired by his message and religious language would consider new actions and thoughts that would cohere to what Cadman felt was the exemplary Christian life. Cadman believed that it is a minister's duty to guide the imagination-inspired activity produced by a creative mind and he maintained that the resulting thought and action of creative imagination should be carried out in the name of Christian ecumenism. Cadman held to this theory as an ideal. He did not believe that all listeners/readers would respond alike. But he believed that, through an appeal to the creative imagination, a minister had the power to inspire positive activity, including Christian ecumenism. ${ }^{22}$

In Imagination, Cadman explained the process of creative imagination more fully than he had in Imagination and Religion. From past experience and present sensation,

\footnotetext{
${ }^{22}$ Cadman's belief about how imagination can inspire ecumenism is the subject of Chapter IV of this study.
} 
Cadman argued, the imagination "builds a universe of its own upon what it has experienced. ${ }^{, 23}$ The universe built by imagination is an inner world that is unique to every individual. In other words, God created the universe that all humans share, but each individual, through creative imagination, takes the substance of the God-created universe and creates a universe of their own design within their minds. "Every human being occupies two worlds," Cadman argued. "The first is one in which we all share alike. The second and more intimately our own is that potential and infinite world which is 'of imagination all compact,' and in it we are free to create or to destroy."24 The final words of this quotation are vital for understanding the power of imagination in Cadman's theory. The inner world can incubate a positive, creative, religious life. The creation of inner worlds influences the outer world that all humans share. An individual takes in outer world phenomena through the functions of imagination, the inner world shapes how the phenomena will be formed into mental images and, therefore, influences the thoughts and actions of the individual. This faculty, Cadman admitted, can be used positively or negatively. The inner world can privatize religion by way of its exclusiveness. Because of the inner world's negative possibilities, Cadman felt that a minister should guide Christian adherents in how they managed their inner world. The inner world can be used for creation as well as destruction. With proper religious guidance, Cadman argued, the inner world can serve as a place for positive creation. Because the inner world depends on imagination's connection to the outer world, the inner world is not off limits to ministers. Cadman felt that positive religious language guided the inner world in a positive direction. Imagination's three functions allow the common individual to make

\footnotetext{
${ }^{23}$ Cadman, Imagination, 15.

${ }^{24} \mathrm{Ibid}$.
} 
sense of the Divine, to come into contact with the Divine, and to produce positive religious activity that meets the demands of the Christian God.

Being central to Cadman's epistemology, imagination proves foundational for both positive and negative developments. Ecumenism is a positive possibility. In Imagination and Religion, Cadman included a lecture entitled "The Perils of Imagination" that laid out a number of negative possibilities. Cadman included psychoanalysis (which he deemed "sex-obsessed") and decadent literature (with an emphasis on the work of Oscar Wilde) in the lecture. But Cadman was not satisfied in picking a bone with secular culture. Even in Imagination, where his focus leaned toward the secular world, Cadman dealt little with the negative attributes of imagination in a secular life. The "self-elected purveyors of pornography," Cadman felt, will always play a part in the modern world. ${ }^{25}$ But the degenerate mind which produces creatively is not dangerous in itself because it will always constitute a minority. Cadman remained confident in this assertion.

Ignorance proves more perilous for the religious imagination than "pornography." Cadman urged his audience to regard the advances of modern science in their process of finding religion within. Both science and religion have a place in the healthy religious mind. Cadman wrote,

Fictitious fences between science and religion are rapidly broken down today because men's ideas of the intelligent nature of causation have expanded. Not a few of the controversies upon which the Church wastes valuable time and strength are superfluous because the facts that settle the issues are commonly known to scholars. Their acceptance by believers ought not to be rendered too costly by love of debate. Nor should religious imagination turn a deaf ear when summoned by humanity's undeniable experiences to nobler interpretations of God's limitless universe. $^{26}$

\footnotetext{
${ }^{25}$ Cadman, Imagination and Religion, 86.

${ }^{26}$ Ibid., 57.
} 
Both science and religion, Cadman felt, were guilty of ignoring one another. Imagination allows direct knowledge of God, but a lack of worldly knowledge renders this power hollow. Cadman believed in the unity of knowledge; and he believed that the absence of any portion of knowledge constitutes a weakness. The danger of this absence of knowledge manifests itself, Cadman argued, in the misuse of imagination in general. The most immediate danger to the imagination, the most perilous of perils, comes from religious culture rather than secular culture. Sectarianism, for Cadman, epitomizes the negative abilities of the human imagination. "The sectarianism that weakens Christianity to this hour is ... largely traceable to ... imagination," explained Cadman. "Its intense provincialism continues to multiply barriers which shut out far more than they enclose. ${ }^{27}$ Sectarianism, Cadman believed, can be propagated if a person's religious imagination is not properly guided. For instance, the inner world of imagination can privatize and isolate religious experience. Cadman argued that sectarianism prospers when the privatization of religion occurs. Therefore, he sought to guide the respective inner worlds of his listeners/readers in a manner that strengthened empathy and connected believers rather than in a manner that enabled the privatization of religion. Cadman, as a Christian minister, had the ability to break down sectarian barriers by impeding the growth of negative religious imagination and by planting seeds for positive growth. In many ways, by expanding the imagination of his audience, Cadman sought to "enlarge the areas of sacred learning" in order to make "ample room" for the recognition of similarity and the respect of difference within the individual listener's or reader's

\footnotetext{
${ }^{27}$ Ibid., 70.
} 
religious worldview. ${ }^{28}$ Rather than isolating religious experience, the inner world, Cadman felt, should connect individuals. "In what sphere of life, then, at present, is the largest scope offered to imaginative activity?" Cadman asked. The answer, he argued, was Christian ecumenism. "It is but a step from images stimulated by the senses to the sympathetic uses of this faculty," Cadman wrote. "The heart is enlarged, its insight deepens, the mind becomes creative, and piles up grateful experiences from the transfigured events it absorbs. Desirable progress in ... religious pursuits is thus rendered possible. ${ }^{30}$ Cadman recognized that the inner world can incubate negativity and cause an individual to focus on dissimilarity of religious beliefs. With the proper guidance of a minister, however, this negative course can be averted and the inner world can be used for strengthening empathy among religious adherents. If empathy is strengthened, Cadman argued, then similarity of belief between Christians will be recognized over dissimilarity of belief.

Cadman built a philosophy around the utilization of religious imagination. ${ }^{31}$ The typical religious adherent, Cadman theorized, can make sense of the Divine by

\footnotetext{
${ }^{28}$ Ibid.

${ }^{29}$ Ibid., 53.

${ }^{30}$ Cadman, Imagination, 22.

${ }^{31}$ Although religious imagination found favor with the onset of the Great Depression, it faced a direct threat from within the academic ranks of Protestantism in the years following the economic calamity. The theology of Schleiermacher, Beecher, and Cadman found a worthy opponent in the theology of Karl Barth. Cadman died before Barth's brand of theology found its greatest popularity in the United States. Yet he lived to witness the winds of change. Karl Barth published his commentary on The Epistle to the Romans in 1922. A Swiss-theologian, Barth targeted liberal Protestants who based theology on feeling and religious experience. Barth disagreed with the liberal construction of God as a piece of knowledge that humans cannot possess. Barth's theology clashed with Cadman's theory of imagination - especially Cadman's belief that creatively imagining the Word of God put an individual in touch with the Divine. For Barth, God is knowable through reason, not through feeling or imagination. God can be an object of knowledge because he allows man to know Him through grace. Grace, therefore, constitutes a distinguishable event. Through recognition of this event, an individual can possess knowledge of God. Barth's most important work, the multi-volume Church Dogmatics, largely falls beyond the scope of Cadman's life. The first volume, although published in 1932, never found its way into Cadman's writings. Barth's early work, however, did influence the direction of American theology during Cadman's lifetime. See Barth's Epistle to the Romans (1922), translated with commentary in a 1963 edition from Oxford University Press.
} 
identifying the "good" in past experience and in mankind's history; an individual can, then, come into contact with the Divine by translating religious language, whether spoken or written, into mental images; and lastly, through the faculty of creative imagination, an individual can use the connection to the Divine to produce positive religious activity in the external world. Cadman urged his listeners/readers to understand that the positive religious activity produced by a creative imagination should be geared towards the unification of Christianity. Thus is Cadman's theory of imagination. Even from the popular pulpits at Central Congregational and the Bedford Y.M.C.A., however, Cadman's reach in communicating and employing his theory was limited. For his theory of imagination to resonate and to enable the widespread progress of ecumenism, Cadman knew that he had to shape his teachings and utilize methods by which he could reach the widest possible audience. He found both the methods and approach to effective teaching in the realm of what shall be termed "popular theology." Over time, Cadman came to utilize the resources of mass media and popular theology so effectively that, in 1930, at the ecumenical Life and Work Conference at Chexbres, Switzerland, Archbishop Nathan Söderblom of Sweden would hail him with the title "Good Prince of the Power of the Air."32

\footnotetext{
${ }^{32}$ Henry Smith Leiper and Edward Daniel Staples, Dr. S. Parkes Cadman: Preacher, Pastor, and Ecumenical Prophet (Boston: The Congregational Christian Historical Society, 1967), 56.
} 


\section{CHAPTER III:}

\section{S. PARKES CADMAN AND POPULAR THEOLOGY}

Despite the abstractions prevalent in Cadman's theory of imagination, the Brooklyn minister was pragmatic in his worldview. Cadman tailored his views on imagination to the average person. For the religious imagination of Christian adherents to be guided properly, he believed, imagination had to be reached on a level of significant breadth. Two criteria had to be met before effective dissemination of Cadman's theory of imagination took place: first, the message had to be communicated to as many people as possible; second, the substance of the message had to be simple, accessible, and inclusive. These criteria form the contours of what, in this study, shall be termed popular theology. Cadman used popular theology to spread his messages about imagination to a mass audience.

Although not a term used during the interwar years, popular theology is helpful in categorizing theology crafted for the understanding of a mass audience. Defined as the system of inquiry and the method of discourse applied to questions concerning Christianity, popular theology is "popular" in that it is suited to the understanding of the average person. In addition to religious imagination, Cadman's popular theology dealt with methods of effective communication and is, in this sense, conceptually similar to missiology, the study of missionary activity within Christian theology. The utilization of 
a popular theology enabled Cadman to reach an audience larger than that afforded to academic theologians.

Cadman believed that Christianity should be simple and accessible. In this case, simplicity applied to the substance of beliefs as well as to the language used in communicating the beliefs. In Ambassadors of God (1920), Cadman traced this notion to The Imitation of Christ (ca. 1418) by Thomas à Kempis.' Cadman thought highly of the theological tenets developed in Medieval Europe and the work of Kempis, he felt, was especially important. Kempis persuasively argued that Jesus's life and work provide an exemplary text for any problem an individual may face. In Jesus, Cadman found a man who communicated in simple, easy to understand language, utilizing the tools available to him to spread his message. Cadman believed that ministers, as "ambassadors of God," should strive to imitate the life of Jesus in this manner. Although the modernity of $1920 \mathrm{~s}$ America provided many tools not available to Jesus, Cadman believed that mass media was in accordance with this belief.

Ministers from most Christian denominations utilized popular theology during the American interwar years by spreading simple messages through print media and radio. Religious figures as diverse as Harry Emerson Fosdick (Northern Baptist) and Charles E. Coughlin (Roman Catholic) spread their messages in print and over the airwaves. Because of its widespread usage, popular theology came to mean different things to different ministers during the 1920s and 1930s. Although most ministers believed in the promise of mass media, a minority of ministers emphasized the threat posed by such

\footnotetext{
' S. Parkes Cadman, Ambassadors of God (New York: The Macmillan Company, 1920), 248.
} 
tools. ${ }^{2}$ This divergence of opinion transcended both denominational lines and the broader labels of liberal and fundamentalist.

Radio, in the view of some ministers, was a stain on American culture and religious life. For these ministers, a popular theology that utilized mass media posed a threat to Christians. Radio was a tool of corruption and the technology hurt church attendance. The latter constituted the most common complaint. Radio removed "the need for a physical community of worshipers, warned Presbyterian Edward Young in 1923," and therefore "removed the 'sense of fellowship in worship, the inspiration of human faces, and the offering of united prayer' that was essential to true spiritual experience." Young feared that radio worship created a community apart from "brick-and-mortar" churches where Christians physically gathered to worship. Radio privatized religion and, therefore, constituted a peril. Nevertheless, ministers who distrusted the marriage of religion and mass media represented a minority. ${ }^{4}$

Cadman saw radio as an educational opportunity and emphasized the medium's promise rather than its threat. Although wary at first about radio's potential to reduce church attendance, he came to believe strongly in its power to spread religious conviction rather than diminish it. In a 1928 article from the Federal Council Bulletin, Cadman made his feeling about radio's potential clear,

As these experiences, gained by actual radio contacts, grew from more to more, it dawned upon me that I ought to dedicate all I am or can hope to be to so providential an opportunity. Musicians, educators, scientists, statesmen and dramatists were quick to seize its skirts. Their concerts, addresses and plays

\footnotetext{
${ }^{2}$ Douglas Carl Abrams, Selling the Old-Time Religion: American Fundamentalists and Mass Culture, 1920-1940 (Athens, GA: University of Georgia Press, 2001), 99.

${ }^{3}$ Douglas B. Craig, Fireside Politics: Radio and Political Culture in the United States, 1920-1940 (Baltimore: The Johns Hopkins University Press, 2000), 274.

${ }^{4}$ Robert S. Fortner, Radio, Morality, and Culture: Britain, Canada, and the United States, 1919-1945 (Carbondale, IL: Southern Illinois University Press, 2005), 109.
} 
speedily won millions of constituents. Surely religion, which is the first business of a free people, should be placed where it belongs in radio's splendid realm - at the front. Thanks to the generous provisions of the broadcasting authorities, it has had an unprecedented hearing in the past decade. And its future is so radiant with promise that moderate forecasts would sound like wild predictions. ${ }^{5}$

This quotation provides insight into Cadman's ministry. Like many in the $1920 \mathrm{~s}$, he believed that radio could be a powerful educational tool. Douglas B. Craig labels this view "radio exceptionalism," defining the concept as "the belief that radio was a very different medium to its predecessors and one possessed of a special destiny." ${ }^{, 6}$ Radio, in other words, because of its scope and reach, had a higher purpose.

Craig argues that this ideology shaped how radio listeners received religious information and how individual speakers approached the medium. Radio, as it was regulated in the United States, restricted the content of religious broadcasting. NBC's Committee on Religious Broadcasting heavily regulated what was acceptable over the air. CBS designed a similar set of policies. In a nutshell, the religious broadcasting policies of NBC and CBS noted that "religious radio could not purport to 'act' or 'represent the Church in America,' and therefore could not divide its audience theologically or proselytize." "If a minister desired to speak over either of the two major networks, then the message conveyed had to be non-denominational. Cadman agreed with the nondenominational nature of religious radio, arguing that "if the Christian church were to use radio effectively, it would have to emphasize the one eternal voice of God rather than the faith's manifold forms." ${ }^{.8}$ When speakers violated religious broadcasting guidelines, the networks took action. For example, when Father Coughlin failed to tone down his anti-

\footnotetext{
5 "Dr. Cadman to Become 'International Minister of the Air'," Federal Council Bulletin, October, 1928, 15.

${ }^{6}$ Craig, Fireside Politics, xvii.

${ }^{7}$ Fortner, Radio, Morality, and Culture, 109.

${ }^{8}$ Ibid., 111.
} 
Hoover and anti-Semitic rhetoric in October 1931, CBS banned the controversial priest from network stations. ${ }^{9}$ In January 1932, CBS banned Reverend Herman J. Hahn, minister of the Salem Evangelical Church of Buffalo from affiliate station WGR, Buffalo. Hahn had been paying $\$ 49$ a week for a fifteen-minute Sunday afternoon slot on WGR. When Hahn insulted big business (remarking that it was "stupid" for businesses to ask employees for "charity" during an economic depression) on January 2, 1932, CBS banned him on January $9 .^{10}$

Popular theology disseminated through radio often bled over into other forms of media. Cadman's radio sermons are an example. In 1925, the Brooklyn Daily Eagle ${ }^{11}$ printed a weekly "sermon edition" that contained transcriptions of Cadman's radio sermons. ${ }^{12}$ According to Leiper and Staples, the Daily Eagle, in 1925, had a circulation of twelve-thousand readers. ${ }^{13}$ During the same period, Cadman published a daily questionand-answer column in the New York Herald Tribune. Thus, Cadman's radio oratory reached people through two different media, newspaper and radio. ${ }^{14}$

In addition to radio and newspaper work, Cadman published a number of books during the interwar years. As Joan Shelley Rubin demonstrates, popular religious books in interwar America were diverse in content. Cadman's books, all with Christianity as their central focus, range in topic from christology to imagination to the search for

\footnotetext{
${ }^{9}$ Donald Warren, Radio Priest: Charles Coughlin, the Father of Hate Radio (New York: The Free Press, 1996), 37.

10 "The Air is Reserved for Conventional Religion," The Christian Century, January 20, 1932, Vol. 49, 78.

${ }^{11}$ According to the Brooklyn Daily Eagle website, http://www.brooklyneagle.com, the Daily Eagle was published as a morning newspaper from 1841 until 1955. From 1955 until 1996, the Daily Eagle was published as the Daily Bulletin.

${ }^{12}$ Henry Smith Leiper and Edward Daniel Staples, Dr. S. Parkes Cadman: Preacher, Pastor, and Ecumenical Prophet (Boston: The Congregational Christian Historical Society, 1967), 18.

${ }^{13}$ Ibid.

${ }^{14}$ This duality may have given Cadman's work high-brow/low-brow crossover potential. For those inclined to believe that the ephemeral nature of radio, and its often low-brow programming, rendered the medium a sub-par source of education and information, Cadman's radio work that appeared in print may have been more likely to appeal to their sensibilities.
} 
individual happiness. As a popular speaker dealing with a diverse audience, Cadman found occasion to comment on most of the consuming issues of his day. Cadman discussed racism, the "modern" woman, juvenile delinquency, academia, military issues, politics, and more in his written works. Cadman's print work is prolific. And unlike his radio work, his writings are still extant. But his print output slowed with the onset of the Great Depression. The economic calamity hit newspapers hard; book sales suffered as well. Radio, however, weathered the storm more easily. One factor was that, as the technology improved, the price of a new radio decreased. As Steve Craig points out, "At first, the impact on the fledgling radio manufacturing industry appeared to be catastrophic as the demand for new sets dropped dramatically. The industry's response was to simplify designs, streamline production methods, and lower retail prices, with the average cost for a new radio falling from $\$ 136$ in 1929 to just $\$ 47$ by 1932 . As the economy began to stabilize, radio manufacturing quickly recovered, and by 1935 annual set production was back to pre-crash levels." ${ }^{15}$ Cadman's written work slowed with the onset of the Great Depression, but his radio work continued steadily.

Cadman's utilization of mass media met one criterion of popular theology in that it enabled him to reach a mass audience. The second criterion was that messages had to be simple, accessible, and inclusive. "Religion is God's free gift; to be taken as that and nothing else," Cadman wrote. "The moment its professors begin to fence it in, claim precedence in it, or invent speculations to check its unrestrained flow they damage its serenity and thwart its appeal. Much depends on the manner of the gospel's presentation

\footnotetext{
${ }^{15}$ Steve Craig, Out of the Dark: A History of Radio and Rural America (Tuscaloosa, AL: The University of Alabama Press, 2009), 77.
} 
and still more on the spirit in which it is presented." ${ }^{, 16}$ Moreover, in 1929, a Review of Reviews article entitled "Preaching to a Nation," quoted Cadman as saying that when preaching to a mass audience it is proper to preach "simple Christianity" rather than "fractional Christianity." 17 Three works that span the scope of this thesis and that are, in individual ways, exemplary of Cadman's ministry illuminate how he expressed ideas in print and over the radio: Cadman's sermon "Faith's Coronation" from Hobart D. McKeehan's Great Modern Sermons (1923); the collection of radio question-and-answer transcriptions Answers to Everyday Questions (1930); and Adventure for Happiness (1935).

"Faith's Coronation" features early forms of ideas found in Cadman's discussions of imagination. The sermon is based upon I Timothy I, Verse Five: "Now the end of the commandment is charity out of a pure heart, and of a good conscience, and of faith unfeigned." Focusing on the words "faith unfeigned," Cadman established his main point early on, arguing that faith, unlike intellectualism, is available and accessible to everyone. This argument is central to his popular theology. "For intellectualism often changes its fashion, and indeed is rapidly changing it now," Cadman wrote. "But the God-given trust fastened on external realities does not have to change. It is independent of the clearest and most cogent brains; and as available for all creatures as air or light." ${ }^{, 18}$ Calling upon the accessibility of a key feature of religious worship and making that central to his argument is a hallmark of Cadman's popular theology. Religious worship, he explained, is not about accessing arcane truths. The most important aspects of religion are available

\footnotetext{
${ }^{16} \mathrm{~S}$. Parkes Cadman, Adventure for Happiness (New York: The Macmillan Company, 1935), 291.

17 "Preaching to a Nation," Review of Reviews, February, 1929, Vol. 79, 132-134.

${ }^{18}$ S. Parkes Cadman, "Faith's Coronation," in Great Modern Sermons, ed. Hobart D. McKeehan (New York: Fleming H. Revell Company, 1923), 42.
} 
to everyone. "Let us cling to its simplicity," Cadman implored. ${ }^{19}$ A religion of the people is accessible to the people. "Faith unfeigned" is not available only to the intellectuals because the "theological training of seminaries and colleges does not impart faith unfeigned. Be that training liberal or conservative, [theological training] is necessarily secondary, and has been overestimated in the Church. The gifts of God are not commandeered by instructors, however sincere or erudite." ${ }^{20}$ As Cadman communicated these ideas about the accessibility of faith, he intended that listeners/readers would grow confident in their ability to attain the level of religiosity available to all. Through his use of language, then, Cadman coaxed his readers/listeners to forget their inabilities and to focus on their abilities. Religion is about what an individual can do rather than what a person cannot do. Cadman's Christianity, especially in its popular vein, was a religion of promise.

Cadman was straightforward about what faith could accomplish. Towards the end of the text, he wrote that faith "should be as altruistic in us as it was in the Master. Then the souls of the believers and the soul of the Church Universal alike shall be as a sea of glass mingled with fire, embracing peace and power, replete of force without waste, and of tranquility with fervor." ${ }^{21}$ Faith brought believers together. Like Cadman's theory of imagination, faith, as an aspect of religion shared equally among Christian adherents, had the power to bridge gaps and unite individuals. By focusing on a tenet of religion available to all, Cadman emphasized similarity over dissimilarity. The accessible in his popular work is key to the ecumenical. Cadman's language in "Faith's Coronation"

\footnotetext{
${ }^{19}$ Ibid., 48.

20 Ibid., 40.

21 Ibid., 48.
} 
remained simple, accessible, and straightforward. In the context of this simplicity, Cadman emphasized the ecumenical message that was central to his ministry.

Answers to Everyday Questions (1930) provides insight into Cadman's radio work. More than any other text, Answers illuminates the substance of Cadman's popular theology in the context of a mass medium. Consisting of selections from the questionand-answer session Cadman conducted during the course of his radio work from 1925 to 1930, Answers has yet to be investigated by scholars in the field of interwar history. The book went through only a single printing and has been out of print since the 1930s. The chapters, diverse in content, range from groupings of questions concerning "Domestic Relations" to "Americana" to "Philosophy, Theology and Science."

Early in the text, Cadman answered a question that got to the heart of his popular theology: "Would you kindly state briefly the essential elements for a religious faith which an average man can accept and live by?" Cadman's response covered his belief that the central tenets of religion are simple and accessible. "Such a faith centers around the three realities of Fatherhood, Sonship, and Brotherhood," Cadman began. "To love and trust God as our Father and to serve men as our brothers is the secret of personal character, peace, and moral influence. Nothing could be simpler than this process, yet nothing is more far-reaching in its effect on life. It is religion pure and undefiled.,22 These words reflect the criteria for Cadman's popular theology.

Another listener asked, "In the last analysis, is not religion mainly a matter of doctrines, rites, and ceremonies?" Cadman, in answer to this question, drove home the central point of his ministry. "No," Cadman replied, "it is mainly an expression of man's

\footnotetext{
${ }^{22}$ S. Parkes Cadman, Answers to Everyday Questions (New York: The Abingdon Press, 1930), 37.
} 
essential nature. All the materials for a religion of some sort are in the human heart.",23 Religion is not found in the depths of intellectual vigor, not in seminaries; it is found in the faculty of man's natural inclinations towards thinking and living. Doctrines, rites, and ceremonies (all matters that divide Christian denominations) are secondary to the religion found in man's heart.

Occasionally Answers gives voice to the cynical listener who attempted to corner Cadman with the claim that the minister simplified religion because such a maneuver helped Christianity avoid the pitfalls imposed upon it by reason and logic. In these instances, Cadman revealed his deep learning and breadth of understanding. Simplicity, he demonstrated, did not signify dearth of knowledge or lack of intellectual depth. For example, one listener wrote to Cadman, asking, "Since God created all things and pronounced them good, since he is omnipresent (that is, present everywhere) and omnipotent (possessing all power), who created evil and the devil, and gave evil its prevalence and power?" Cadman tackled the question with ease, relying on established theories of theodicy. ${ }^{24}$ Considering Cadman's affinity for medieval theology, it is not surprising that he relied on the common Augustinian explanation that evil is nothing per se; that evil constitutes a privation. Augustine argued that evil stems from God's gift of free will. People choose to be evil or people choose to be good. Without free will, Augustine argued, neither is possible. ${ }^{25}$ Evil is a privation in that it is simply a lack of good. Cadman agreed with Augustinian theodicy. In response to the question, he cited the "free development" of human personality, "which requires the exercise of the power of

\footnotetext{
${ }^{23}$ Ibid., 147.

${ }^{24}$ Theodicy means "the justification of God." In Christianity, the term refers to the study of evil.

${ }^{25}$ For Augustine's view on evil, see his On Free Choice of the Will. Thomas Williams' 1993 translation is the most respected to date.
} 
choice between good and evil.... [Life] includes evil because the good can be realized only by man's conscious victory over evil. ${ }^{.26}$ When tested, Cadman displayed the erudite side of his intellect.

Adventure for Happiness (1935) fits into an interesting genre of literature. The self-help book, although not born in 1930s America, found impetus for growth during the Depression and burgeoned into the mass industry that it constitutes in the twenty-first century. Of course, the most popular self-help book in the period was How to Win Friends and Influence People (1936) by Dale Carnegie, still in print after eighty-five years. Cadman's Adventure for Happiness, even in its time, did not find the popularity enjoyed by Carnegie's text. However, Cadman's book sold well enough to warrant two editions from Macmillan Company. ${ }^{27}$ Written in accessible language, Adventure for Happiness is light on complex arguments. Cadman arranged the book for easy perusal with stand-alone chapters that provide individual strategies and arguments. Overall, Cadman argued that happiness can be found through several avenues, none of which is exclusive and none based on social standing. All avenues begin within. The individual finds happiness in the natural processes of the mind rather than in the external world.

In the book, Cadman emphasized the importance of imagination, arguing that imagination plays a significant role in staving off unhappiness and in maintaining a positive outlook on life. "The modern triumph of external things should not cause us to forget that imagination is the creator and destroyer of happiness," Cadman wrote. ${ }^{28}$ Unlike the outside world, imagination works for the individual. Man has complete control of its faculties. Therefore, a healthy imagination leads to happiness because a person

\footnotetext{
${ }^{26}$ Cadman, Answers to Everyday Questions, 185.

27 "Books Recently Received," The Journal of Religion Vol. 16, No. 2 (April, 1936): 252.

${ }^{28}$ Cadman, Adventure for Happiness, 187.
} 
chooses how to interpret the events of the surrounding world. Cadman used the specter of the Great Depression to argue that imagination is the most important tool in fighting against the oppressiveness of economic hardship. Imagination that works against the individual causes unhappiness and inspires fear in the minds of those faced with hard times. An imagination controlled by the individual works as a coping mechanism, and allows the individual to experience happiness despite the conditions of the outside world. Imagination, properly controlled, can inspire happiness. In the text, Cadman sought to make the connection between imagination-inspired happiness and Christianity explicit. When happiness "loses touch with the harmony which faith in God's purposes inspires, its fine glow is obscured and its peace departs." ${ }^{29}$ Happiness without religion is hollow, Cadman argued. In this sense, religion is necessary for maintaining happiness.

Cadman's utilization of a popular theology rested upon two criteria: the ability to reach a mass audience and the ability to communicate in simple, accessible, and inclusive messages. The most important aspects of religion are found within common individuals rather than in seminaries. For Cadman's theory of imagination to be practical it had to be molded to the specifications of a popular theology. In an age where religious leaders from diverse denominations held differing views on mass media and how to communicate Christian thought to a popular audience, Cadman believed that a properly crafted message conveyed through print or radio would lead to desirable goals in a modern Christian world. Ecumenism remained Cadman's ultimate goal in kindling and guiding the imagination of a mass audience. Ecumenical activity, he believed, required a proper religious imagination. Popular theology brought Cadman in contact with the people he

\footnotetext{
${ }^{29}$ Ibid., 291.
} 
wished to unite. But in what manner could messages about imagination, disseminated within the contours of a popular theology, inspire Christian ecumenism? 


\section{CHAPTER IV:}

\section{ECUMENISM IN THE MINISTRY OF S. PARKES CADMAN}

In 1921, S. Parkes Cadman published an essay entitled "Can a Divided Church Meet the Challenge of the Present World Crisis?" in Frederick Lynch's volume, The Problem of Christian Unity. Cadman wrote,

The quarrels of these dogmatists, which absorbed their minds, are short-lived and unimportant when viewed in the light of the eternal cosmos which is being built up by every Christ-like interest of mankind. Their historic separatisms have ceased to charm. Enlightened spirits, weary of arid controversies, feel that the matters about which those controversies centered are as dust in the balances when compared with the glorious truths upon which all Protestants are agreed. ${ }^{1}$

As the events of the 1920 s demonstrated, "separatism" in many quarters, especially Protestantism, persisted. But Cadman, in 1921, meant something deeper than the immediate cooling-off of sectarianism. He argued that the unification of Protestantism and of Christianity as a whole would be a process subject to the limits of natural maturation. In other words, true ecumenism has to occur in a step-by-step fashion; unity has to start small and grow large. Cadman urged his readers to understand that the $1920 \mathrm{~s}$, despite the calamity following World War I and the separatism prevalent in Protestantism, could be the beginning of a far-reaching ecumenical process because the world, up to that point, had never been more interconnected.

\footnotetext{
${ }^{1}$ S. Parkes Cadman, "Can a Divided Church Meet the Challenge of the Present World Crisis?" in The Problem of Christian Unity, ed. Frederick Lynch (New York: The Macmillan Company, 1921), 5. The recovery of the "world" after World War I is the "World Crisis" Cadman referred to in the title.
} 
Ecumenical activity, in the context of this study, is defined as the method by which doctrinal differences between adherents of denominational Christianity are reduced or eliminated in favor of recognizing similarity of belief. Ecumenism, which according to Thomas E. Fitzgerald comes from the ancient Greek word ekoumeni, meaning "the whole world," 2 seeks to erase denominational lines within Christianity and to assuage misunderstandings in order to establish a single Church Universal. Christian unity, Cadman believed, is a very real possibility if ministers guide the imagination of individual Christian adherents with the methods of a popular theology.

Frederick Lynch's The Problem of Christianity (1921) is helpful for understanding where Christian ecumenism stood at the beginning of the American interwar years. One particular essay, "Obstacles in the Way," by Bishop William Fraser McDowell (1858-1937), establishes a sense of the disordered state of ecumenical efforts at that point in history. McDowell explained that the main obstacle facing Christians who desired unity was that no true definition of Christian unity existed. "Christian Unity is an idea which has not yet taken an organic, visible, definite form," McDowell wrote. "You cannot point any group of thoughtful people to the thing and say: 'That is it." ${ }^{33}$ In 1921 , only a few wide-reaching ecumenical organizations existed, including the Federal Council of the Churches of Christ in America (FCCCA) which had been around for thirteen years. When Cadman began his push for ecumenism, therefore, the modern idea of Christian unity was still underdeveloped. Ecumenical organizations had existed in America since the nineteenth century: the International Sunday-School Lessons (1872),

\footnotetext{
${ }^{2}$ Thomas E. Fitzgerald, The Ecumenical Movement: An Introductory History (Westport, CT: Praeger Publishers, 2004), 3.

${ }^{3}$ William Fraser McDowell, "Obstacles in the Way," in The Problem of Christian Unity, ed. Frederick Lynch (New York: The Macmillan Company, 1921), 50. McDowell served as a Bishop in the Methodist Episcopal Church from 1904 until 1937.
} 
the Federation of Churches and Christian Workers of New York City (1895), and the World's Student Christian Federation (1895) are examples. ${ }^{4}$ However, there was no consistency about how to approach Christian ecumenism in the nineteenth century and through the first two decades of the twentieth century. The field, therefore, was very open when Cadman entered the scene.

In the years following World War I, two ecumenical approaches prevailed: organic union and federal union. Organic union is the unification of Christian denominations under a common authority and under common, shared doctrine. Organic union is full union. The American Council on Organic Union (1920-1921) is an example of this approach. Federal union, in contrast, calls for the establishment of a federation of churches. The federation is a "cooperative organization ... in which each constituent Church retains its full independence and liberty of action. Such federation involves the setting-up of a special central organization, but does not involve the fusion of the existing organizations of the separate bodies." The FCCCA (1908-1948) is an example of the federal union approach. Cadman believed that both organic and federal union were possible. Practically, however, he maintained that federal union should precede organic union.

In the $1920 \mathrm{~s}$, the federal union approach, with few exceptions, dominated the ecumenical scene. ${ }^{6}$ In a decade characterized by Protestant conflict, several key religious figures, popular and academic, joined Cadman in his quest for Christian unity. Francis J.

\footnotetext{
${ }^{4}$ Don Herbert Yoder, "Christian Unity in Nineteenth-Century America," in A History of the Ecumenical Movement, 1517-1948, ed. Ruth Rouse et al. (Philadelphia: The Westminster Press, 1967), 253.

${ }^{5}$ Ruth Rouse, ed., A History of the Ecumenical Movement, 1517-1948 (Philadelphia: The Westminster Press, 1967), 807.

${ }^{6}$ Martin E. Marty, Modern American Religion Volume 2: The Noise of Conflict, 1919-1941 (Chicago: The University of Chicago Press, 1991), 33-34.
} 
McConnell, Bishop of the Methodist Episcopal Church, Pittsburgh, and Charles S. Macfarland were two popular religious figures vocal in the ecumenical cause. Both McConnell and Macfarland contributed essays to the 1929 book entitled Twenty Years of Church Federation: Report of the Federal Council of the Churches of Christ in America, 1924-1928. ${ }^{7}$ Edited by Samuel McCrea Cavert, the volume celebrated the growth of the FCCCA and covered, specifically, the years when Cadman served as president. Cadman's essay in the volume, entitled "The Genius of the Federal Council," centered on the "peace and oneness of the earliest Christian discipleship," and argued that the FCCCA, although it had achieved much in its twenty years, had much further to go before its mission was complete. $^{8}$

Academics also published works on the federal union approach in the 1920s and 1930s. William Adams Brown, theologian and professor at Union Seminary, is an example. In The Church in America (1922), Brown, like Cadman, argued that federal union and organic union should be viewed as two steps in the same direction rather than competing strategies. "Federal union may be a step toward organic union," Brown wrote. ${ }^{9}$ Francis J. McConnell reviewed Brown's text in 1923 for The Journal of Religion and commented that Brown's discussion of Christian union contained "a vast amount of shrewd observation ... which the practical men of practical affairs in the various churches

\footnotetext{
${ }^{7}$ In 1929, McConnell was president of the FCCCA and Macfarland was Social Services Secretary of the FCCCA. In addition, Macfarland, in 1929, served as the Protestant representative on NBC's Committee on Religious Activities.

${ }^{8}$ S. Parkes Cadman, "The Genius of the Federal Council," in Twenty Years of Church Federation: Report of the Federal Council of the Churches of Christ in America, ed. Samuel McCrea Cavert (New York: Federal Council of Churches, 1929), 17.

${ }^{9}$ William Adams Brown, The Church in America: A Study of the Present Conditions and Future Prospects of American Protestantism (New York: The Macmillan Company, 1922), 177.
} 
would do well to note."10 The most visible outlet for academics participating in ecumenical activity during the interwar years was the "Ecumenical Seminar," held at Geneva, Switzerland annually from 1933 to 1936 . Sponsored by the Universal Christian Council, the "Ecumenical Seminar" featured lectures from academic religious figures such as William Adams Brown, Karl Barth, Paul Tillich, and Reinhold Niebuhr. ${ }^{11}$ During the interwar years, the push for federal union found support among popular religious figures like Cadman and among academic figures such as Brown.

Cadman developed strategies for fighting Christian sectarianism throughout his ministry. Popular theology provided the method for beginning the process of ecumenism by allowing a minister to reach and guide the faculty of imagination. Cadman's written work reveals this strategy. Ecumenism, in the 1920 s, required the employment of a popular theology because, as Cadman lamented, the Church, up to that point, had unquestionably failed to heal schisms. In Ambassadors of God (1920), Cadman urged fellow ministers to reach out to the common people with simple and accessible theology because non-scholarly laymen were the people who could, realistically, make the process of ecumenism a simpler task for denominational leaders. ${ }^{12}$ Ecumenism, for Cadman, began in living rooms rather than classrooms. This is not to marginalize the importance of education in Cadman's ministry. It is to say that proper education is not relegated to the academy. Communication through popular media can also serve as an educational tool.

\footnotetext{
${ }^{10}$ Francis J. McConnell, "Review: A Survey of Protestant Christianity in America," review of The Church in America: A Study of the Present Conditions and Future Prospects of American Protestantism, by William Adams Brown, The Journal of Religion, March, 1923, 205.

${ }^{11}$ Nils Karlström, "Movements for International Friendship and Life and Work, 1910-1925," in A History of the Ecumenical Movement, 1517-1948, ed. Ruth Rouse et al. (Philadelphia: The Westminster Press, 1967), 557.

${ }^{12}$ S. Parkes Cadman, Ambassadors of God (New York: The Macmillan Company, 1920), 132-139.
} 
Although Cadman never wrote a single volume on ecumenism, several of his books contain lectures, chapters, or essays that deal directly with the topic. Cadman's life serves the purpose of a text as well. His participation in ecumenical conferences including the Life and Work Conference in 1925, the Conference on Faith and Order in 1927, The World Alliance in 1931, and the Modern Churchman's Conference in 1931 in addition to the various positions he held in relation to ecumenical activity, are an important part of his legacy and an illustrative aspect of his effort. Cadman's work reveals his thoughts on ecumenism, both theoretical and concrete. The work, too, reflects the importance he placed on popular theology and imagination in ecumenism; in Cadman's ministry all three were distinct parts of a singular process. Cadman envisioned ecumenism that began at the base and forced movement at upper levels - grass-roots ecumenism rather than trickle-down ecumenism. Cadman reached a mass audience, sought to guide the imaginations of individual Christians, and provided ecumenism as an avenue for channeling what he hoped to be the resulting activity.

Between 1920 and 1936, Cadman formulated and preached both a theology of ecumenism and a plan for an ecumenical theology. A theology of ecumenism is a body of thought centering on the manner in which ecumenism can be accomplished. An ecumenical theology, in contrast, is the system of beliefs that can be used by a joint body of churches. A theology of ecumenism is necessary for both organic and federal union, whereas an ecumenical theology is necessary for organic union, but is not necessary for federal union. Cadman's theology of ecumenism relied heavily on his theory of imagination and he expounded it in his written work and over the airwaves of NBC. 
Cadman's plan for an ecumenical theology, which shall be discussed after his theology of ecumenism, is found in Ambassadors of God (1920).

Cadman's theology of ecumenism found a popular audience through station WEAF. Through the question-and-answer session of his program, he explained his ideas on the matter. Two questions from Answers to Everyday Questions (1930) help illuminate the direction of Cadman's theology of ecumenism as he approached it through a mass medium. The first question asks, "What is your opinion about all the Protestant churches becoming united? What would be the name if they should do so?" In reply, Cadman confidently stated, "that the drift of divinely guided events is toward the ultimate consolidation of institutional Protestantism I for one have no doubt whatever." ${ }^{13}$ Cadman cautioned that ecumenism has to happen over time and develop gradually. "Let this fruit of unity ripen naturally," he implored. "The reintegration of separate churches is resentful of haste, and the slower it is the longer they will afterward hold together." ${ }^{, 14}$ Because the 1920s offered many resources hitherto unknown to the Christian minister, the decade, Cadman believed, constituted the perfect time for beginning the process of ecumenism. With the ability to connect to a large audience of people through media, namely the radio, ministers could realistically construct and disseminate ecumenical messages. One audience, hypothetically, paralleled one flock, one Church. People, Cadman knew, had never been more interconnected.

The second question from Answers is less general and gets to the heart of Cadman's connection between ecumenical activity and imagination: "In what possible ways can you really unite Christians who hopelessly differ in doctrine and worship? Why

\footnotetext{
${ }^{13}$ S. Parkes Cadman, Answers to Everyday Questions (New York: The Abingdon Press, 1930), 124.

${ }^{14}$ Ibid. As far as the name is concerned, Cadman answered that a unified Church should be called The Christian Church.
} 
prolong the agony? Can you not see that the differences I mention in this letter are permanent?" In response, Cadman asked, "Is the agony quite so severe as you assert?"15 Then, with zeal, he explained how imagination is the key for Christians seeing beyond the temporal and finding what is common in their faith. Christians should realize that the religious imaginations of their forebears birthed the very things Christians can celebrate as unifying factors. Cadman called upon his Hymnal as an example. "'In the Hymnary 1 use daily," he answered, "Saint Bernard sings with Whittier; and a Greek hymn of the eighth century, 'Christian, Dost Thou See Them?' is close to John Milton's austere but perfect artistry. Cardinal Newman's lyric, 'Lead, Kindly Light,' is well to the front beside the composition of Sarah Flower Adams, an elect lady of the Unitarian Church, who wrote, 'Nearer, My God, to Thee." ${ }^{17}$ As Cadman's theory of imagination attested, religious imagination can connect an individual to the Divine through the "vivification" of the present world and through the process of creation. Minds aware of contemporary doctrinal difference wrote the hymns that Cadman cited. And yet, the hymns found common ground when their authors' imaginations connected with the Divine.

Imagination links, Cadman stressed. As a linking device, imagination involves Cadman's theory of the two worlds - the world of God's creation and the unique inner world of individual creation. The inner world of imagination forged the hymns Cadman cited. In the same manner that the cited authors found common ground in their inner worlds, so, too, could all religious adherents. Cadman wanted his followers to realize this: "Sacred song, aided by the universal speech of music, has already made a breach in the barriers

\footnotetext{
${ }^{15}$ Ibid., 125.

${ }^{16}$ Hymnal and Hymnary are common names for collections of hymns.

${ }^{17}$ Cadman, Answers, 125.
} 
that separate God's children." "Imagining the Divine, something all Christians can accomplish, transcends the most basic doctrine and provides for the recognition of similarity. The inner world allows individuals to recognize similarity of belief because, within it, the temporal is stripped away in the face of the eternal. Cadman reiterated this point in Adventure for Happiness (1935). Of the hymnal unity inspired by imagination, he wrote,

There is a saying that the book of Psalms, the ancient hymnary of the Jewish Church, contains the whole music of the heart of man swept by the hand of his Maker. Nothing comparable with the best of these lyrics exists elsewhere even in the Bible. They know no confines of creed or country and controversy is foreign to their temper. The love of them has proclaimed a truce between warring sects and their praise has inspired numberless Christian tributes of prose and poetry. Their prayers and supplications have voiced the highest aspirations and deepest needs of Jew and Christian alike. They are a divine gift to human imagination and happiness. ${ }^{19}$

Cadman used direct language. Hymns are a divine gift; creativity, in relation to religion, is a divine gift. Because imagination is shared, it has the power to connect individuals. Cadman spread this belief by utilizing a popular theology, as Answers to Everyday Questions attests. He spread the message over the radio and then had it printed. Furthermore, he communicated the idea in straightforward, down-to-earth language. In general, Cadman displayed little patience for those who claimed the impossibility of Christian union. Not only did he confront questions over the airwaves, he also sounded off on purveyors of popular culture who tolled "Protestantism's knell." In 1928, Cadman targeted crime writer and journalist Herbert Asbury. ${ }^{20}$ Asbury, The Literary Digest reported, "sees signs of decay on every hand. The break between the Fundamentalists and Modernists, he asserts, has hopelessly divided the Church and

\footnotetext{
${ }^{18}$ Ibid.

${ }^{19}$ S. Parkes Cadman, Adventure for Happiness (New York: The Macmillan Company, 1935), 285.

${ }^{20}$ Herbert Asbury authored several well-known books, including Gangs of New York (1928).
} 
caused a revolt amongst millions of nominal believers which a befuddled and ignorant clergy are unable to halt." 21 The article turned to Cadman for rebuttal. "It is the voice of repressed vindictiveness rather than of scientific criticism which assails the reader's ears, ",22 he replied. Cadman demonstrated that he had no time for those who judged Christian schisms as irredeemable. He knew that Christian unity was possible. Asserting the impossibility of ecumenical progress, he felt, negatively colored memory and history in the minds of Christian adherents.

Memory, Cadman argued, plays an important role in ecumenical activity. In Imagination (1930), Cadman urged Christians to "purify" their memories in order to marginalize matters of religious difference in history and in their individual experiences. ${ }^{23}$ Cadman used the term "purify" in connection to Paul's command that "whatsoever things are true ... honest ... just ... pure ... lovely ... and of good report ... think on these things." 24 Cadman defined "pure" memory as memory that stored "grateful images and satisfying conceptions. ${ }^{, 25}$ A purified memory, in other words, was devoid of negative experience (religious dissimilarity included). Cadman remained vague on what "negative experience" entails. However, his main point was that Christian adherents should focus on the positive in history and in their individual experiences. A "purification" of memory, in this sense, would enable ecumenical activity in that it would allow for the marginalization of dissimilarity of belief among individual Christians. Too many people, Cadman argued, focus on conflict when calling upon individual past experience or recalling historical events. The naysayer calls the unification of Christianity

\footnotetext{
21 “An Asbury Tries to Toll Protestantism's Knell," The Literary Digest, March 3, 1928, 28-29.

${ }^{22}$ Ibid.

${ }^{23}$ S. Parkes Cadman, Imagination (New York: E.P. Dutton \& Co., Inc.), 70-71.

${ }^{24}$ Ibid., 71.

${ }^{25}$ Ibid., 70.
} 
impossible. Negative examples such as Herbert Asbury led individuals to focus on conflict when calling upon the examples of history. A purified memory, in contrast, can force individuals to focus on the positive rather than the negative, on similarity rather than difference.

Cadman believed that placing conflict on a pedestal in memory prolongs sectarianism. A minister can easily touch upon conflict and negatively guide the imagination. Thus, the methods afforded by popular theology can be harmful. Popular media in the 1920s and 1930s, Cadman felt, was a battlefield. He knew that he had to give his full effort toward helping listeners and readers focus on the peaceful and the positive in their collective and individual memories. Other ministers helped divide Christians by shouting 'foul' and pointing out conflict after conflict. They focused on difference. For example, Reverend Robert P. Shuler (known as "Fighting Bob" Shuler) on KGEF, Los Angeles, frequently used his airtime "to attack [Roman Catholicism] and members thereof, thus serving to promote religious strife. ${ }^{26}$ Cadman sought, in contrast, to purify memory, to teach his listeners/readers that memory can be used to find similarity in both life and religion.

The focal point of a positive memory, Cadman maintained, is the life of Jesus. "The center of Christian Faith is neither a creed nor a book, but a Person and a Life," Cadman wrote, echoing the words of Bishop J.B. Lightfoot of Durham. ${ }^{27}$ Jesus represents peace rather than conflict. Calling upon Jesus's life, therefore, allows a Christian to focus on the positive. A memory that focuses on Jesus constitutes the purest type of memory. With a purified memory, Cadman argued, conflict can be marginalized and difference, as

\footnotetext{
26 "Freedom for the Radio Pulpit," The Christian Century, January 27, 1932, Vol. 49, 112.

${ }^{27}$ S. Parkes Cadman, Christ of God (New York: The Macmillan Company, 1929), 67.
} 
it exists in modern Christianity, can be overlooked. A purified memory is a prerequisite for successful ecumenical activity.

Religious imagination, for Cadman, is the most powerful tool in a theology of ecumenism. Quite simply, imagination allows, through the power to reproduce the past, the power to bring the present world to life in the mind (to vivify the present), and through the power of creation, an individual to create a unique inner world in which the individual can witness the similarity of belief among Christians. Cadman argued that the inner world, with the proper guidance of a minister and the effort of the individual, can be ideal for the realization that, underneath the various doctrines of denominational Christianity, Christians are more similar than dissimilar in their beliefs. The inner world allows the individual to surpass the shallow religious differences prevalent in the outer world. Cadman believed that the inner world enables individuals to view the outer world with heightened empathy and, therefore, allows them to recognize similarity of belief over doctrinal difference.

Christian unity, Cadman knew, is a complex matter. For ecumenism to take place, a strong foundation has to be constructed. Christian unity requires a level playing field; the accessibility and inclusiveness of a popular theology provide this democracy. Christian unity requires the awareness of similarity beyond the complications of doctrine; imagination allows this recognition to occur. The practice of making individuals aware that their religious imagination contains such a power is a form of mental mobilization. Once Cadman mobilized the Christian population at the grass-roots level, denominational leaders, he believed, would find putting the process of federal union (and eventually organic union) in motion a simpler procedure. Denominational leaders would find a 
willing audience among the mass of Christian adherents in the United States and beyond. With the flock mobilized, the various Christian churches could participate in the necessary conferences and conduct the necessary intra-religious dialogue for attaining the Church Universal, Cadman hoped.

Ambassadors of God (1920) contains Cadman's outline of what he felt to be a possible ecumenical theology. Cadman called this construction New Theology, although he made clear that the title was "hackneyed" and generic. ${ }^{28}$ Cadman argued that an ecumenical theology has to focus on the most basic and simple aspects of the Christian faith. Interpretations that are not found in scripture have to be looked at anew. If, in any way, these interpretations depart from the original spirit of the text, then the interpretations have to be discarded. The insight of patristic writers and medieval mystics is too important to disavow without giving a close scrutiny. However, Cadman argued, if these writings do not cohere with the spirit of original scripture, no matter how attractive, they deserve dismissal. Only by getting to the heart of scripture and promoting a system of belief that does not stray from a pure Christianity can Christians develop an ecumenical theology rather than simply a theology of ecumenism. Cadman failed to acknowledge that phrases such as "spirit of original scripture" and "pure Christianity" are open to interpretation. In Ambassadors, Cadman took the meaning of these phrases for granted, failing to explain them fully. Regardless, if Christians achieve a system of belief that hails "pure Christianity" and adheres to the "spirit" of the Bible, he argued, "Then the plain people to whom [Christianity] is addressed will rejoice in it and demonstrate that they are as deeply concerned about religious matters as thinkers who have filled

\footnotetext{
${ }^{28}$ Cadman, Ambassadors, 163.
} 
volumes with learned technicalities and subtleties of speech." ${ }^{29}$ The democracy of Cadman's statement stands out. By developing a system of belief on which to base a universal Christianity, Cadman proposed to level the playing field. The statement coheres with Cadman's general beliefs about religion. In Cadman's view, Christians are equal in their ability to believe, in their ability to employ faith, and in their ability to utilize imagination..$^{30}$

In Cadman's theology, the clarity of simple doctrine reflects the purity of the belief. Complicated doctrine smells of misdirection. That is not to say that in-depth systematic theology means to deceive. But Cadman, in this instance, sought to absorb Christianity from the point of view of a non-scholarly layman. If theology appears complicated and inaccessible, Cadman believed, the common man or woman will be less likely to trust it. Moreover, complicated theology lends itself to prolonging sectarianism. Ministers who concentrate on conflict can shape small issues of doctrine into mountainlike obstacles. By eliminating this tool, by putting doctrine equally in the hands of clergy and laymen, a significant power can be wrested from the hands of those who prolong sectarianism. Simple doctrine leaves less room for interpretation. An attempt to view religion through the eyes of the common man harkens back to Jesus's approach to teaching, Cadman believed. The employment of simple, straightforward, and understandable doctrine is the only way to achieve widespread unity. This approach taps into what Cadman referred to as the "consciousness of Jesus," meaning that the approach captures the spirit of Christ. Cadman remained general in his outline of a possible

\footnotetext{
${ }^{29}$ Ibid.

${ }^{30}$ Cadman extended this democracy to cover the restrictions of gender and race prevalent in his time. An advocate of both women's rights and racial equality, Cadman believed that all humans enjoyed the same ability to employ religious faith and exercise imagination. Both women's rights and racial equality are discussed in Cadman's Answers to Everyday Questions.
} 
ecumenical theology. He did so because he believed that a true ecumenical theology had to be arrived at jointly by the denominations involved in unification. Regardless, in Ambassadors of God, Cadman demonstrated his thoughts on how the formulation of an ecumenical theology should proceed.

Although an orator first and foremost, Cadman participated in ecumenical activity on more than one level. As mentioned in Chapter I, in addition to spreading his ideas from the pulpit, in print, and over the radio, Cadman participated in a number of ecumenical conferences in the 1920s and 1930s. Moreover, as president of the FCCCA, he led an important organization of Protestant ecumenism. During Cadman's tenure as president, The Reformed Church in the United States and The Hungarian Reformed Church in America came together in organic union. ${ }^{31}$ The most symbolic gestures of Cadman's career, however, came in 1925 and 1931 when the Congregational Churches merged with The Evangelical Protestant Churches of North America (EPCNA) and the General Convention of the Christian Church, respectively. Cadman's church, Central Congregational, was the second largest Congregational church in the United States when he assumed the pulpit in 1901. Thus, Cadman played an important symbolic role in seeing these unions come to fruition. In 1925, the Congregational Churches and the EPCNA merged in organic union. At the time, Cadman was president of the FCCCA and, as such, gave his full support to the merger. The name Congregational Churches became the moniker for the merged denomination.

\footnotetext{
${ }^{31}$ Stephen Charles Neill, "Plans of Union and Reunion, 1910-1948," in A History of the Ecumenical Movement, 1517-1948, ed. by Ruth Rouse et al. (Philadelphia: The Westminster Press, 1967), 496.
} 
Talk of unification had been carried on by members of the Congregational Churches and the General Convention of the Christian Church since the $1880 \mathrm{~s}^{32}$ After several decades, the denominations agreed to come together in federal union. As Stephen Charles Neill explains, "In 1931 the Congregational Churches and the Christian Church had come together on the basis that 'this union shall be conditioned upon the acceptance of Christianity primarily as a way of life, and not upon uniformity of theological opinion or any uniform practice of ordinances.' The unification of the two bodies in states and districts was completed by $1936 .{ }^{33}$ By uniting in federal union, the two denominations bypassed the immediate melding of doctrine.

In "Can A Divided Church Meet the Challenge of the Present World Crisis?," Cadman concluded that sectarianism weakened Christianity and limited its influence. Unification was the only way to stop this slide. Cadman never feared that Christianity would falter completely, however. "People in this world need religion," he told journalist William G. Shepherd in 1924. "“They need it like they need sleep, or food, or water. And by religion I don't mean religious theories. I mean a belief in a supernatural God; a belief in immortality; a belief that helps people to build their lives. People will have religion, because they must have it. The demand for it is born in them."34 Regardless, if Christians wanted their religion to retain a moral influence on the modern world, they needed to unify.

Cadman's approach to ecumenism, federal and organic, remained heavily theoretical throughout his ministry. Despite several examples of success in his lifetime,

\footnotetext{
${ }^{32}$ Yoder, "Christian Unity in Nineteenth-Century America," 258.

${ }^{33}$ Neill, "Plans of Union and Reunion, 1910-1948," 480.

${ }^{34}$ William G. Shepherd, Great Preachers as Seen by a Journalist (New York: Fleming H. Revell Company, 1924), 92-93.
} 
Cadman's theology of ecumenism bore less fruit than some of his contemporaries would have liked. His ecumenical method, therefore, did not escape criticism. For example, Christian Century lamented, upon Cadman's death in 1936, that the minister had put less than his full energy into the attainment of the Church Universal during his lifetime. ${ }^{35}$ The article stated, "It was the strong desire of some his friends that Dr. Cadman would launch out boldly on a crusade for the organic unity of Protestantism. At one moment three or four years ago he seemed to be on the point of doing so. But the spirit of a crusader was not in him. " ${ }^{36}$ Cadman, the writer lamented, had not pursued Christian ecumenism to his full ability. Theodore Louis Trost backed up the Christian Century's opinion in 2002, commenting that Cadman "lacked a plan for bringing into being a united church." opinion that Cadman did not put his full energy into ecumenical work and that, in general, he lacked a plan for ecumenism forms the consensus view on Cadman's quest for attaining the Church Universal.

The 1936 editorial and Trost, however, missed the mark in their assessments. Viewing Cadman's career in hindsight, it is easy to assume that, because he brought about few tangible ecumenical results, he failed to put his full effort into the task of unity or that he lacked a plan for unification. Such an assessment, however, fails to grasp Cadman's belief in the power of imagination. Cadman's plan, although unorthodox, is implicit in the body of writings he left behind. He maintained that guiding the imagination of individual Christian adherents served as an important stepping stone in bringing about Christian ecumenism because imagination heightened empathy and

\footnotetext{
35 "His Christian Leadership," The Christian Century, July 22, 1936, Vol. 53, 1003.

${ }^{36}$ Ibid.

${ }^{37}$ Theodore Louis Trost, Douglas Horton and the Ecumenical Impulse in American Religion (Cambridge, MA: Harvard University Press, 2002), 68.
} 
allowed for the marginalization of religious difference. Proper religious imagination among Christians set the stage for ecumenical conferences and intra-religious dialogue. In addition to expounding his theory of imagination, Cadman gave his time to participating in ecumenical conferences and helped in merging the Congregational Churches with two Protestant denominations. As president of the FCCCA, Cadman worked to expand the organization's goals to encompass the future unity of all Christians rather than Protestants alone.

Cadman's greatest effort lay in bringing ecumenism to the people, in moving the Church by touching the imagination of its common adherents. Results, in this instance, are hard to measure. Yes, Christianity, even Protestantism, remained and remains deeply divided along denominational lines. But Cadman made an effort in a unique realm - the realm of religious imagination. Did his effort fail? Ultimately, it appears so. But failure does not equal lack of effort or the lack of a plan. Genius is not always found in victory. The men who lose often make the largest contributions to progress. Cadman illustrated this point in Imagination (1930) - a prophecy of his own legacy. Speaking on Bernard Palissy's tireless efforts in crafting glazed porcelain in France, Cadman wrote that, even though Palissy succeeded,

had he not revolutionized the ceramic art of Europe he would have been nearly as great in defeat as he was in victory. His indomitable will was sustained by that image of the glazed porcelain vase which obsessed his mind. The prophet, poet, artist, philosopher, scientist and humanitarian who exhibit a kindred fortitude endure as 'seeing the invisible.' They feel obligated to plant their convictions in other breasts. ${ }^{38}$

Cadman traveled a similar road, with an "indomitable will" kept alive by the "image" of the Church Universal. He, too, felt obligated to plant his "convictions in other breasts."

\footnotetext{
${ }^{38}$ Cadman, Imagination, 37-38.
} 
Although his efforts bore little fruit, Cadman's thoughts on ecumenism, religious imagination, and the interaction of the two, influenced ministers and theologians such as Douglas Horton in the years following his death. Such a contribution to American theology is a success rather than a failure. Cadman spent his life pursuing the Church Universal. In the end, his effort means more than the results garnered. For S. Parkes Cadman, the road to the Church Universal bore witness to his most inspired and innovative work. 


\section{CONCLUSION}

S. Parkes Cadman was a popular religious figure and an important Christian thinker during the American interwar years. Although largely forgotten today, he made significant contributions to Christian theology and to the marriage of religion and mass media. He built a theory of imagination upon the philosophical constructions of Schleiermacher and Beecher and found a popular audience in the 1920s and early 1930s. Although Cadman could have chosen to deal with any number of topics through his emphasis on religious imagination, he chose Christian ecumenism - the issue that he felt was most urgent. Cadman believed that true Christian unity would take many generations to achieve. During his own lifetime he witnessed several unions, organic and federal, within Protestantism, including two involving the Congregational denomination.

Cadman's unorthodox plan for attaining the Church Universal is embedded in the oratory and writings he produced over the course of his ministry, especially between 1920 and 1936. Trost is wrong when he comments that Cadman lacked an ecumenical plan. ${ }^{1}$ Cadman consistently argued that reaching and guiding the imagination of individual Christian adherents provided an important starting point for ecumenical progress. Properly guided religious imagination among Christians, he believed, would set the stage for ecumenical conferences and intra-religious dialogue. Mass media and

\footnotetext{
${ }^{1}$ Theodore Louis Trost, Douglas Horton and the Ecumenical Impulse in American Religion (Cambridge, MA: Harvard University Press, 2002), 68.
} 
accessible messages, Cadman argued, enabled a minister to most effectively reach the imagination of Christian adherents.

Two fields of Christian theology bear witness to Cadman's legacy: ecumenism and religious imagination. Leiper and Staples, in S. Parkes Cadman: Preacher, Pastor, and Ecumenical Prophet (1967), demonstrate Cadman's zeal for ecumenical activity. The authors credit Cadman with influencing the formation of the World Council of Churches, a body formed twelve years after his death. As president of the FCCCA from 1924-1928 and Radio Minister of the FCCCA from 1928-1936, Cadman helped the Protestant ecumenical organization strengthen its position in American religious life. Cadman led the FCCCA at a pivotal time in the history of American Protestantism. During his tenure, the FCCCA expanded upon its original goals, seeking the ultimate union of all Christian churches. The union of Protestantism remained a prerequisite, but after the 1920s, Protestant union came to be seen as a stepping stone for Christian unity among all denominations.

Cadman's most revealing ecumenical legacy is found in the life and work of Douglas Horton (1891-1968). Trost explains that Douglas Horton was a "key but overlooked figure among American ecumenists." Horton "played a particularly crucial part in establishing and redefining important institutions such as the United Church of Christ, the Harvard Divinity School, and the World Council of Churches - not to mention his contributions in fostering closer ties between Protestants and Roman Catholics."3 Cadman's approach to ecumenism greatly influenced Horton. Growing up in Brooklyn, and as a member of Central Congregational Church, Horton absorbed Cadman's

\footnotetext{
${ }^{2}$ Ibid., 2.

${ }^{3}$ Ibid.
} 
preaching from the age of fourteen onward. "From S. Parkes Cadman, his minister and counselor," Trost writes, "[Horton] learned to deplore narrowness in relation to denominational affiliation [...] Cadman was also a mentor for Horton in a number of other ways: as a leader in cooperative religious efforts, as a disciplined learner and teacher, and as a man of the nation and the world."

Cadman's unique theory of imagination also added to American theology. Although marginalized after Barth, imagination did not disappear from Christian thought entirely. The resurrection of religious imagination in the 1970 s and 1980 s owes much to Cadman's life and work. In his investigation of religious imagination in twentieth-century theology, Don M. Aycock explains that "not much that is readily available was written specifically about religious imagination from the 1930 's to the 1960 's.... Beginning in the late 1960 's and lasting until the present, this situation changed dramatically." Theologians published many books and articles on the importance of imagination in theology in the 1970s and 1980s. The most famous of these works, and one that is typical of the trend, is Amos Wilder's Theopoetic: Theology and the Religious Imagination (1976). Like Cadman, Wilder placed emphasis on the creative function of imagination, arguing that the faculty is "far more than mere decoration. It is a vital element of thinking. It is a necessary component of all profound knowing and celebration, all remembering, realizing and anticipating, all faith, hope, and love." Although Wilder did not cite Cadman as inspiration for his views on religious imagination, Wilder was active at the height of Cadman's popularity. Ordained as a Congregational minister in 1926,

\footnotetext{
${ }_{5}^{4}$ Ibid., 41.

${ }^{5}$ Don M. Aycock, "Religious Imagination in Twentieth Century American Theology: A Study of Four Selected Figures" (ThD dissertation, New Orleans Baptist Theological Seminary, 1986), 7.

${ }^{6}$ Ibid., 65.
} 
Wilder served as pastor at First Church of Christ in North Conway, New Hampshire until $1928 .^{7}$

The greatest irony of Cadman's legacy comes in the form of Cadman Memorial Church. In 1942, Central Congregational Church in Brooklyn merged with Brooklyn's Clinton Avenue Community Church, honoring Cadman by using his name. Congregational churches had, up to that point, enjoyed the privilege of self-governance. During the years of World War II, however, a group within Congregationalism began to push for the unification of Congregational Churches and the Evangelical and Reformed Church under a single ruling body. "A joint committee of Evangelical and Reformed and Congregational Christian delegates composed seven drafts of the 'Basis of Union' between March 1943 and November 1946," Trost explains. ${ }^{8}$ Many Congregational adherents rejected the "Basis of Union," a pamphlet that laid out the procedures for unification. The Congregationalists in opposition drafted their own pamphlet, arguing that "In Congregationalism ... only individual churches were empowered to act on their own behalf. No national organization could act for them."9

On April 19, 1949, the Cadman Memorial Church filed a lawsuit against Helen Kenyon, moderator of the Congregational Churches, claiming that the council formed around the "Basis of Union" lacked the authority to impose unity on individual Congregational churches. The New York Supreme Court ruled in favor of the Cadman Memorial Church on January 26, 1950, allowing Cadman's former pulpit to retain its autonomy. The trial, commonly referred to as the "merger trial," "Cadman trial," or Cadman v. Kenyon, placed the name of S. Parkes Cadman in direct opposition to an act

\footnotetext{
${ }^{7}$ Ibid., 59.

${ }^{8}$ Trost, Douglas Horton, 82.

${ }^{9}$ Ibid., 83.
} 
of Christian unity. For a man who spent a significant part of his life pursuing the Church Universal, Cadman v. Kenyon stands as Cadman's most ironic legacy, one that the minister would have considered tragic.

Cadman should be remembered as a popular religious figure who pursued Christian unity rather than for the sectarian trial that bears his name. Over the course of his ministry, Cadman touched many lives and preached and wrote on a wide range of topics. He contributed original thought to the methods of communication used in Christianity and he added to the development of American theology. A practical man, Cadman sought ecumenism because he felt the world was better off under the influence of a strong Christianity. Writing in 1922, Cadman spoke of the "world's necessities" and argued that, "The prime service [Protestants] can render the world is to set our own house in order, that we may wisely apply the teachings of the New Testament Evangel and of Old Testament ethics."10 The modern world, he felt, was too strong for a divided Christianity. In the face of this assessment, Cadman developed a unique theory of imagination, he utilized the methods of a popular theology, and he pushed with his greatest effort for Christian ecumenism. Cadman's absence from the historical record is a sore oversight. It is time that his name and his effort in attaining the Church Universal return to discussions of interwar Christianity and popular culture.

\footnotetext{
${ }^{10}$ S. Parkes Cadman, "Protestantism and the World's Necessities," The North American Review, Vol. 216, No. 803 (Oct., 1922), 438.
} 


\section{REFERENCES}

\section{PRIMARY SOURCES}

Augustine. On Free Choice of the Will. Translated by Thomas Williams. Indianapolis: Hackett Publishing Co, 1993.

Barton, Bruce. The Man Nobody Knows: A Discovery of Jesus. Indianapolis: BobbsMerrill, 1925.

Barth, Karl. The Epistle to the Romans. Translated by Edwyn C. Hoskyns. London: Oxford University Press, 1922, 1963.

Brown, William Adams. The Church in America: A Study of the Present Conditions and Future Prospects of American Protestantism. New York: The Macmillan Company, 1922.

Cadman, S. Parkes. Adventure for Happiness. New York: The Macmillan Company, 1935.

. Ambassadors of God. New York: The Macmillan Company, 1920.

. Answers to Everyday Questions. New York: The Abingdon Press, 1930.

. "Can a Divided Church Meet the Challenge of the Present World Crisis?" In The Problem of Christian Unity, edited by Frederick Lynch, 1-10. New York: The Macmillan Company, 1921.

. Charles Darwin and Other English Thinkers. Boston: The Pilgrim Press, 1911.

. Christianity and the State. New York: The Macmillan Company, 1924.

. Imagination. New York: E.P Dutton \& Co., Inc., 1930.

. Imagination and Religion. New York: The Macmillan Company, 1926.

. "Faith's Coronation." In Great Modern Sermons, edited by Hobart D. McKeehan, 35-48. New York: Fleming H. Revell Company, 1923. 
. Parables of Jesus. Philadelphia: The Mackay Company, 1931.

. The Christ of God. New York: The Macmillan Company, 1929.

."The Genius of the Federal Council." In Twenty Years of Church Federation: Report of the Federal Council of the Churches of Christ in America, 1924-1928, edited by Samuel McCrea Cavert, 17-28. New York: Federal Council of the Churches of Christ in America, 1929.

. The Prophets of Israel. New York: The Macmillan Company, 1933.

. The Religious Uses of Memory: A Sermon. Boston: The Pilgrim Press, 1912.

Peace. New York: E.P. Dutton \& Co., Inc., 1929.

Carnegie, Dale. How to Win Friends and Influence People. New York: Simon and Schuster, 1936.

Johnson, E.H. The Religious Use of Imagination. New York: Silver, Burdett \& Company, 1901.

McDowell, William Fraser. "Obstacles in the Way." In The Problem of Christian Unity, edited by Frederick Lynch, 48-61. New York: The Macmillan Company, 1921.

Schleiermacher, Friedrich. The Christian Faith. Edited by H.R. Mackintosh and James Stewart. Edinburgh: T\&T Clark, 1999.

Schweitzer, Albert. The Quest of the Historical Jesus: A Critical Study of its Progress from Reimarus to Wrede. Translated by W. Montgomery. London: A. \& C. Black, 1911.

Shepherd, William G. Great Preachers as Seen by a Journalist. New York: Fleming H. Revell Company, 1924.

Stead, W.T. If Christ Came to Chicago! What Would Jesus Do? London: 'Review of Reviews' Office, 1899.

\section{PERIODICALS}

Annals of the American Academy of Political and Social Science

Brooklyn Daily Eagle

Cresset

Federal Council Bulletin

Journal for the Scientific Study of Religion

Newsweek 
New York Times

Review of Reviews

The American Monthly Review of Reviews

The Christian Century

The Journal of Religion

The Literary Digest

The North American Review

The Wireless Age

The World's Work

Time

\section{SECONDARY SOURCES}

Abrams, Douglas Carl. Selling the Old-Time Religion: American Fundamentalists and Mass Culture, 1920-1940. Athens, GA: University of Georgia Press, 2001.

Aycock, Don M. "Religious Imagination in Twentieth Century American Theology: A Study of Four Selected Figures." ThD diss., New Orleans Baptist Theological Seminary, 1986.

Barth, J. Robert Sr. Romanticism and Transcendence: Wordsworth, Coleridge, and the Religious Imagination. Columbia, MO: University of Missouri Press, 2003.

Benjamin, Louise M. The NBC Advisory Council and Radio Programming, 1926-1945. Carbondale, IL: Southern Illinois University Press, 2009.

Bynum, Caroline Walker. Jesus as Mother: Studies in the Spirituality of the High Middle Ages. Berkeley, CA: University of California Press, 1982.

Callahan, Richard J. Jr. Work and Faith in the Kentucky Coal Fields: Subject to Dust. Bloomington: Indiana University Press, 2009.

Clark, Clifford E., Jr. Henry Ward Beecher: Spokesman for a Middle-Class America. Chicago: University of Illinois Press, 1978.

Cooney, Terry A. Balancing Acts: American Thought and Culture in the 1930s. New York: Twayne Publishers, 1995.

Craig, Douglas B. Fireside Politics: Radio and Political Culture in the United States, 1920-1940. Baltimore: The Johns Hopkins University Press, 2000.

Craig, Steve. Out of the Dark: A History of Radio and Rural America. Tuscaloosa, AL: The University of Alabama Press, 2009. 
Dorrien, Gary. The Making of American Liberal Theology: Idealism, Realism, and Modernity, 1900-1950. Louisville, KY: Westminster John Knox Press, 2003.

Douglas, Susan J. Listening In: Radio and the American Imagination. Minneapolis: University of Minnesota Press, 2004.

Eliot, Elizabeth Ann. The Crowned Knot of Fire: A Study of the Influence of Medieval Symbolism on Modern Poetry. New York: Vantage Press, 1980.

Erickson, Hal. Religious Radio and Television in the United States, 1921-1991: The Programs and Personalities. Jefferson, NC: McFarland \& Company, inc., 1992.

Fitzgerald, Thomas E. The Ecumenical Movement: An Introductory History. Westport, CT: Praeger Publishers, 2004.

Fortner, Robert S. Radio, Morality, and Culture: Britain, Canada, and the United States, 1919-1945. Carbondale, IL: Southern Illinois University Press, 2005.

Hamlin, Fred. S. Parkes Cadman: Pioneer Radio Minister. New York: Harper \& Brothers Publishers, 1930.

Hangen, Tona. "Man of the Hour: Walter A. Maier and Religion by Radio on the Lutheran Hour." In Radio Reader: Essays in the Cultural History of Radio, edited by Michele Hilmes and Jason Loviglio, 113-134. New York: Routlege, 2002.

. Redeeming the Dial: Radio, Religion, and Popular Culture in America. Chapel Hill, NC: University of North Carolina Press, 2002.

Jones, Edgar DeWitt. American Preachers of To-day: Intimate Appraisals of Thirty-Two Leaders. Freeport, NY: Books for Libraries Press, 1933, 1971.

Karlström, Nils. "Movements for International Friendship and Life and Work, 19101925." In A History of the Ecumenical Movement, 1517-1948, edited by Ruth Rouse and Stephen Charles Neill, 507-596. Philadelphia: The Westminster Press, 1967.

Leiper, Henry Smith, and Edward Daniel Staples. Dr. S. Parkes Cadman: Preacher, Pastor, and Ecumenical Prophet. Boston: The Congregational Christian Historical Society, 1967.

Marty, Martin E. Modern American Religion Volume 2: The Noise of Conflict, 19191941. Chicago: The University of Chicago Press, 1991.

Moore, R. Laurence. Selling God: American Religion in the Marketplace of Culture. New York: Oxford University Press, 1994. 
Neill, Stephen Charles. "Plans of Union and Reunion, 1910-1948." In A History of the Ecumenical Movement, 1517-1948, edited by Ruth Rouse and Stephen Charles Neill, 443-505. Philadelphia: The Westminster Press, 1967.

Newton, Joseph Fort. Some Living Masters of the Pulpit: Studies in Religious Personality. New York: George H. Doran Company, 1923.

Pells, Richard H. Radical Visions and American Dreams: Culture and Social Thought in the Depression Years. Chicago: University of Illinois Press, 1998.

Pringle, Henry F. Big Frogs. New York: The Vanguard Press, 1928.

Rubin, Joan Shelley. "The Boundaries of American Religious Publishing in the Early Twentieth Century." Book History 2 (1999): 207-217, http://www.jstor.org/stable/30227303.

Sutton, Matthew Avery. Aimee Semple McPherson and the Resurrection of Christian America. Cambridge, MA: Harvard University Press, 2007.

Trost, Theodore Louis. Douglas Horton and the Ecumenical Impulse in American Religion. Cambridge, MA: Harvard University Press, 2002.

Vardam, J. Bruce. "S. Parkes Cadman as a Preacher: A Thesis." BDiv thesis, Emory University, 1937.

Warren, Donald. Radio Priest: Charles Coughlin, the Father of Hate Radio. New York: The Free Press, 1996.

Wilder, Amos N. Theopoetic: Theology and the Religious Imagination. Philadelphia: Fortress Press, 1976.

Yates, Frances A. Giordano Bruno and the Hermetic Tradition. Chicago: The University of Chicago Press, 1964.

Yoder, Don Herbert. "Christian Unity in Nineteenth-Century America." In A History of the Ecumenical Movement, 1517-1948, edited by Ruth Rouse and Stephen Charles Neill, 219-259. Philadelphia: The Westminster Press, 1967. 


\section{CURRICULUM VITAE}

NAME: James Coy Hall

ADDRESS: $\quad 54$ Creekside Lane

South Shore, KY 41175

DOB:

Portsmouth, $\mathrm{OH}$ - May 21, 1986

EDUCATION

\& TRAINING: $\quad$ B.A., History

Ashland Community and Technical College 2004-2006

Shawnee State University

2007-2008 